
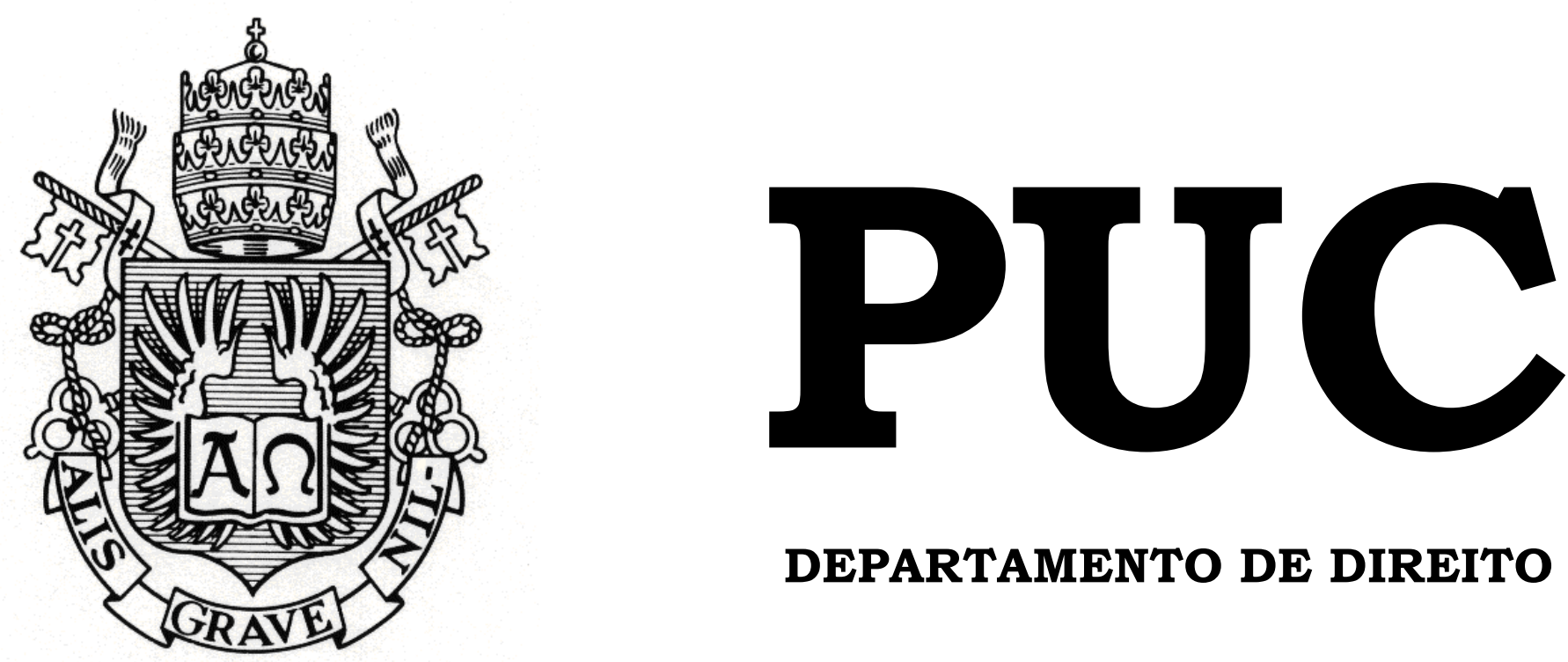

DEPARTAMENTO DE DIREITO

\title{
PASSADO E PRESENTE DA VIOLÊNCIA DO ESTADO CONTRA A MULHER: A JURISPRUDÊNCIA DA CORTE INTERAMERICANA DE DIREITOS HUMANOS E O RELATÓRIO DA COMISSÃO NACIONAL DA VERDADE
}

por

SOFIA TRAVANCAS VIEIRA

ORIENTADORA: Carolina de Campos Melo 2018.2

PONTIFÍCIA UNIVERSIDADE CATÓLICA DO RIO DE JANEIRO RUA MARQUÊS DE SÃO VICENTE, 225 - CEP 22453-900 


\section{PASSADO E PRESENTE DA VIOLÊNCIA DO ESTADO CONTRA A MULHER: A JURISPRUDÊNCIA DA CORTE INTERAMERICANA DE DIREITOS HUMANOS E O RELATÓRIO DA COMISSÃO NACIONAL DA VERDADE}

por

SOFIA TRAVANCAS VIEIRA

Monografia

apresentada

ao

Departamento de Direito da Pontifícia Universidade Católica do Rio de Janeiro (PUC-Rio) para a obtenção do Título de Bacharel em Direito.

Orientadora: Carolina de Campos Melo 


\section{Agradecimentos}

Agradeço à minha professora e orientadora, Carolina Melo, pela minha inserção na área dos direitos humanos, pelo acompanhamento durante minha graduação, como orientadora de iniciação científica e coordenadora de grupos de estudos, pela confiança fornecida para a minha participação nas competições nacional e interamericana de direitos humanos. Por fim, agradeço ainda pela orientação, ajuda e incentivo durante a elaboração deste trabalho.

Gostaria de agradecer ao Grupo de Discussão do Relatório da CNV por tornarem a experiência da leitura e elaboração de um resumo as mais enriquecedoras possíveis com as quais cresci acadêmica e pessoalmente. Com isso, vejo no grupo não só grandes profissionais, mas também grandes amigos.

Agradeço ao Núcleo de Direitos Humanos, seus professores e alunos, pela grande contribuição para a minha formação acadêmica, pelas oportunidades e por ter encontrado ali um lugar na PUC-Rio com o qual me identifico.

Nesses anos de graduação conheci pessoas que tornaram meu dia-a-dia na faculdade mais leve e especial, que deram aquela "ajudinha" na véspera de prova, que me apoiaram quando eu precisava e as quais, hoje, posso chamar de amigas. Assim, agradeço à Alexia, Danielle, Fernanda, Maria Carolina e Vitória.

Família e amigos acompanharam esse longo período de graduação e a elaboração desta monografia com palavras de motivação e compreendendo minha ausência em alguns momentos. Desta forma, agradeço, especialmente, às minha amigas de vida, Giuliana, Julianna Rachel, Marcella e Maria Giulia, por estarem sempre ao meu lado. E também ao meu namorado, Pedro Henrique, que chegou no meio do caos, mas no momento certo para me fazer sorrir.

Por fim, agradeço aos meus pais, Isabel e Francisco, por serem pais incríveis, sempre presentes, desde momentos pessoais até profissionais, apoiando e incentivando meus sonhos, além do meu estudo e trabalho na área de Direitos Humanos. 


\section{Resumo}

O trabalho analisa a abordagem da Comissão Nacional da Verdade sobre a violência do Estado contra a mulher, tratando da violência sexual e de gênero. Faz uso da jurisprudência da Corte Interamericana de Direitos Humanos sobre esse tipo de violação para entender a sua interpretação. Em um primeiro momento, o trabalho apresenta as principais decisões do tribunal sobre violência de gênero, violência sexual, violação sexual, violência sistemática contra a mulher e tortura. Analisa também a violência do Estado contra a mulher no relatório da $\mathrm{CNV}$, seja em sua dimensão normativa, seja por meio da apresentação da narrativa das mulheres vitimas de violência. Finalmente, observa as reparações presentes nas sentenças proferidas pela Corte IDH e sobre as conclusões e recomendações da CNV. Toda a abordagem feita leva em consideração que as violações analisadas ocorreram no passado e continuam sendo perpetradas no presente.

\section{Palavras-chave}

Violência Contra a Mulher. Violência de Estado. Violência Sexual. Corte Interamericana de Direitos Humanos. Comissão Nacional da Verdade. 


\section{Sumário}

Introdução 5

Capítulo 1 - Violência Sexual Perpetrada por Agentes Estatais e a Corte

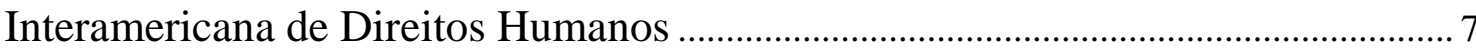

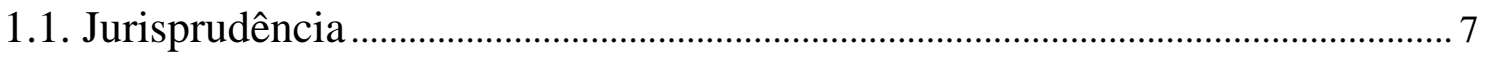

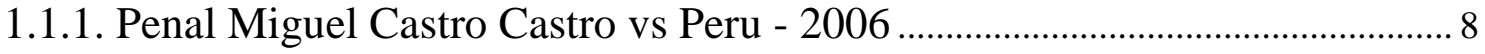

1.1.2. Fernández Ortega vs México - 2010 e Rosendo Cantu vs

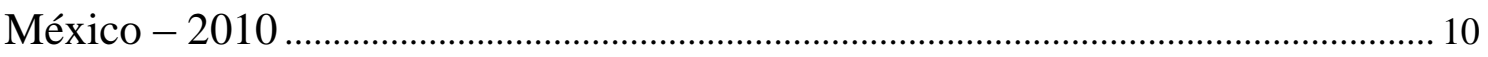

1.1.3. J. vs Peru - 2013 e Espinoza Gonzáles vs Peru - 2014 _.................................. 13

1.1.4. Favela Nova Brasília vs Brasil - 2017 .................................................................. 16

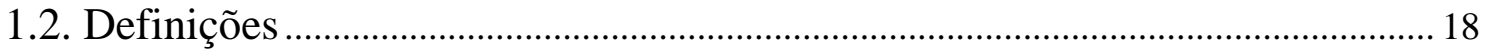

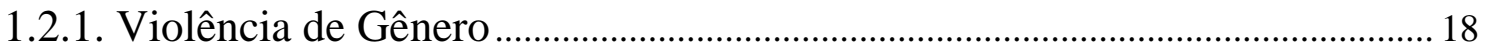

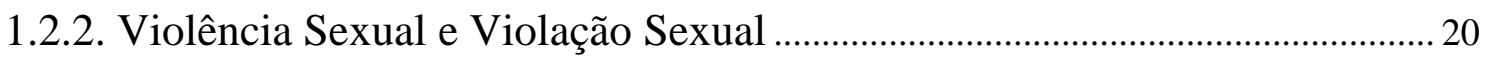

1.2.3. Violência Sistemática Contra a Mulher ….............................................................. 21

1.2.4. Violação Sexual Perpetrada por Agente Estatal - Tortura................................ 21

Capítulo 2 - Comissão Nacional da Verdade: Violência de Gênero e Violência

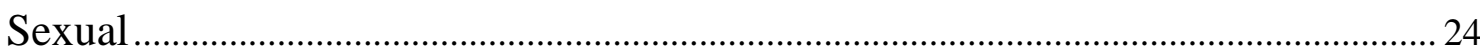

2.1. A Dimensão Sexual e de Gênero da Tortura .......................................................26

2.2. Relatos da Violência Sofrida pelas Mulheres durante a Ditadura ..................... 33

Capítulo 3 - Recomendações da CNV à luz das Reparações da Corte IDH ......... 39

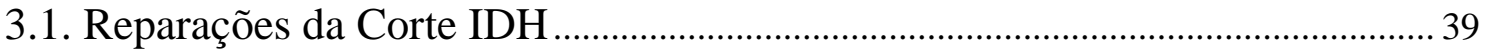

3.2. Reparações para o Brasil no Caso Favela Nova Brasília (2017) ....................... 42

3.3. Conclusões e Recomendações da CNV ................................................................... 44

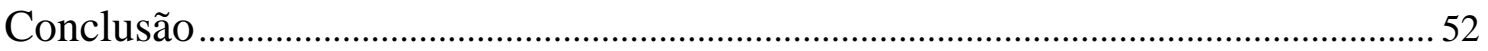

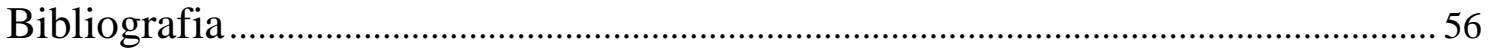




\section{Lista de Abreviaturas}

CADH - Convenção Americana de Direitos Humanos;

CNV - Comissão Nacional da Verdade;

Comissão IDH - Comissão Interamericana de Direitos Humanos;

Corte IDH - Corte Interamericana de Direitos Humanos;

CEDAW - Convenção sobre a Eliminação de Todas as Formas de Discriminação Contras a Mulher 


\section{Introdução}

O objetivo do presente trabalho foi analisar a abordagem feita pela Comissão Nacional da Verdade ("CNV"), da violência de estado contra a mulher, tratando da violência sexual e de gênero, sob o uso das lentes da jurisprudências da Corte Interamericana de Direitos Humano ("Corte Interamericana" ou "Corte IDH").

A escolha do objeto de pesquisa se deu com base na participação, desde de 2015, em grupos de estudos do Núcleo de Direitos Humanos da PUC-Rio, como o Grupo de Discussão do Relatório da CNV e o Simulações e Realidade. Além da participação, em 2018, na "Inter-American Human Rights Moot Court Competition", que teve como tema a violência de gênero. A partir deles foram realizadas pesquisas e discussões acerca do Relatório da Comissão Nacional da Verdade e de casos da Corte Interamericana. Desta forma, essa monografia buscou tratar dos dois temas mais estudados durante a graduação, o relatório da CNV e a violência contra a mulher na Corte IDH.

Além disto, a escolha do referido objeto tem importância no contexto atual, pois explora não só as violações ocorridas no passado, como na ditadura militar brasileira e nos casos da Corte IDH, mas versa também sobre as reparações e recomendações feitas pela CNV e pelo Tribunal as quais tratam do momento atual da violência do Estado contra a mulher.

Com o intuito de realizar esta monografia da forma mais completa possível foi adotado como método de pesquisa analisar os casos mais pertinentes julgados pela Corte Interamericana sobre a violência do Estado contra a mulher para, em seguida, observar a forma utilizada pela CNV para abordar esse tipo de violência e se a mesma está de acordo com os parâmetros do Tribunal.

Quanto à estrutura, o trabalho foi dividido em três partes. $\mathrm{O}$ primeiro capítulo teve por objetivo analisar seis casos da Corte Interamericana: Penal Miguel Castro Castro vs. Peru, Fernandez Ortega vs. México, Rosendo Cantu vs. México, J. vs. Peru, Espinoza Gonzáles vs. Peru e Favela Nova Brasília vs. 
Brasil. Além dessas decisões, foram utilizadas normativas internacionais para, a partir destas, chegar às definiçõoes necessárias para o estudo da violência contra a mulher.

O capítulo seguinte tratou da violência contra a mulher, do conceito de tortura e apresentou narrativas das vítimas presentes no relatório da $\mathrm{CNV}$ já com o intuito de compreender o entendimento utilizado e se o mesmo estava de acordo com o da Corte IDH.

O terceiro capítulo faz a ligação entre o passado e o presente das violações e teve como principal objetivo observar as reparações indicadas nas sentenças da Corte Interamericana dos casos escolhidos anteriormente, além de apreciar as conclusões e recomendações da CNV que versam, principalmente, sobre as violações sofridas pelas mulheres.

Por fim, o trabalho analisa de forma crítica a maneira como Comissão Nacional da Verdade abordou a violência de Estado sofrida pelas mulheres no período ditatorial brasileiro e suas conclusões e recomendações. 


\section{Capítulo 1 - Violência Sexual Perpetrada por Agentes Estatais e a Corte Interamericana de Direitos Humanos}

Os crimes sexuais, em geral, estão relacionados às vítimas mulheres. Isto porque esse tipo de violência atinge a mulher de forma distinta e traz consigo uma hierarquização de gênero. Devido à especificação da violência contra a mulher, é de suma importância que a violência sexual seja reconhecida como grave violação de direitos humanos para a luta pelos direitos humanos das mulheres.

As questões de gênero, assim como a abordagem da violência sexual, chegaram ao Sistema Interamericano de Direitos Humanos com a Convenção de Belém do Pará, em 1994. A partir de então a Comissão IDH passou a lidar com esses assuntos e a tratar de casos de violência de gênero. No entanto, a Corte IDH só veio abordar a questão de gênero no caso Penal Miguel Castro Castro vs Peru, em 2006. Desde então o tema da violência sexual tem sido recorrente no Tribunal.

A violação sexual perpetrada por agentes estatais, assunto principal do capítulo, já foi abordada em diferentes casos pela Corte Interamericana, principalmente por conta de conflitos armados e ditaduras vivenciadas por países do continente latino americano. No entanto, alguns casos escolhidos para serem analisados ocorreram não só em períodos de exceção, ditaduras, como a princípio poderíamos pensar, mas também em épocas de democracia demonstrando que esse tipo de violação também ocorre em períodos democráticos.

\subsection{Jurisprudência}

Serão analisados seis casos da Corte IDH: Penal Miguel Castro Castro vs Peru, Fernández Ortega vs México, Rosendo Cantu vs México, J vs Peru, Espinoza González vs Peru e Favela Nova Brasília vs Brasil. Os casos não são uma lista exaustiva das decisões que tratam da violência do Estado contra a mulher, mas são os que tratam com mais ênfase esses tipos de violações de direitos humanos, sendo abordados em ordem cronológica. O estudo de caso é 
especial para a presente análise tendo em vista que é a partir das decisões de casos que a Corte Interamericana apresenta seu entendimento acerca dos temas. Além disso, é de suma importância compreender a dimensão consolidada no sistema do qual o Brasil participa, tendo em vista que o mesmo deve seguir o entedimento desse sistema ao abordar essas questões internamente.

\subsubsection{Penal Miguel Castro Castro vs Peru - 2006}

O Caso Penal Miguel Castro Castro vs Peru, como já foi dito em momentos anteriores, foi o primeiro caso em que a Corte Interamericana aplicou em sua sentença a análise de gênero. E foi também o primeiro caso a abordar a Convenção de Belém do Pará.

Os fatos do caso ocorreram durante um uma época em que o Peru vivia um conflito entre grupos armados e forças policiais, entre os anos 1980 e $2000 .{ }^{1}$ No período dos acontecimentos, o bloco 1A do Presídio Penal Miguel Castro Castro possuía mais ou menos 135 mulheres e 50 homens presos. Os presos dos blocos $1 \mathrm{~A}$ e $4 \mathrm{~B}$ eram os acusados de crimes contra a pátria e terrorismo. ${ }^{2}$

Em abril de 1992 foi realizada uma inspeção no bloco 1A onde averiguaram que não havia nenhuma arma, explosivo ou buraco de túnel. ${ }^{3}$ Entre os dias 7 e 12 de maio foi realizado o "Operativo Mudança 1" dentro do Penal Miguel Castro Castro o qual tinha por objetivo real atentar contra a vida e integridade dos presos. Atos de violência foram direcionados aos blocos 1A e 4B, onde estavam os considerados terroristas. ${ }^{4}$ Durante a operação foram mortos 42 presos, 175 ficaram feridos e 322 foram submetidos a tratamentos cruéis, desumanos e degradantes. ${ }^{5}$

Após sair dos blocos onde ocorreram os ataques, a maioria dos sobreviventes foi obrigada a ficar na zona conhecida como "terra de ninguém". Nesse local os presos tinham que ficar imóveis, sem abrigo, podendo levantar só

\footnotetext{
${ }^{1}$ Corte IDH. Caso del Penal Miguel Castro Castro Castro vs Peru, p.54..

${ }^{2}$ Ibid. p. 57.

${ }^{3}$ Ibid.

${ }^{4}$ Ibid. p. 58.

${ }^{5}$ Ibid. p.2.
} 
para ir ao banheiro. Além disso, foram submetidos a golpes e agressões. Não receberam alimentação adequada, eram vigiados por agentes estatais armados e com cachorros e caso alguém reclamasse da situação os agentes humilhavam o preso. Dentre essas pessoas havia feridos e mulheres grávidas. Muitos ficaram nessas condições até o dia 22 de maio. ${ }^{6}$

Em sua sentença, a Corte IDH abordou as violências sofridas pelas mulheres e suas perspectivas quando analisou o artigo 5 da $\mathrm{CADH}$, integridade física, em conjunto com a Convenção Interamericana para Prevenir e Punir e Tortura. ${ }^{7} \mathrm{Na}$ sentença foi realizada uma análise, com base em outras decisões ${ }^{8}$, a respeito das condições de detenção compatíveis com a dignidade pessoal e afirmou-se que o Estado é responsável pelos estabelecimentos prisionais e, por isso, deveria garantir condições que respeitem os direitos fundamentais dos presos. ${ }^{9}$ Foi concluído que determinadas formas de tortura afetam as mulheres de forma diferente por causa do gênero e das condições a que foram submetidas, como a falta de atenção às necessidades fisiológicas, o não fornecimento de produtos higiênicos e a negativa de cuidado com as necessidades de saúde pré e pós natal, constituem tortura. ${ }^{10}$

A Corte Interamericana interpretou os artigos 4 (direito à vida) e 5 (direito à integridade pessoal) da CA utilizando-se dos entendimentos presentes na Convenção de Belém do Pará. ${ }^{11}$ A Corte utilizou-se dos artigos 1, 2c, 3, 4 e 7 da Convenção de Belém do Pará para interpretar as obrigações estatais no que diz respeito às mulheres vítimas. Essa não traz direitos novos para as mulheres, mas sim direitos já reconhecidos no Sistema Interamericano com foco na mulher.

O Tribunal entendeu que o envolvimento das mulheres em um conflito armado alterou a percepção da mulher, pois ela se tornou o oposto do que é entendido como "feminino". A participação feminina dentro dos grupos armados

\footnotetext{
${ }^{6}$ Corte IDH. Caso del Penal Miguel Castro Castro Castro vs Peru, p.64-65.

${ }^{7}$ Ibid.p. 109-111.

${ }^{8}$ Corte IDH. Caso García Asto y Ramírez Rojas Vs. Perú. Sentencia de 25 de noviembre de 2005. Serie C No. 137, párr. 221; Caso Raxcacó Reyes vs. Guatemala. Sentencia de fondo de 15 de septiembre de 2005. Serie C No. 133, párr. 95; y Caso Fermín Ramírez vs. Guatemala. Sentencia de fondo de 20 de junio de 2005. Serie C No. 126, párr. 118.

${ }^{9}$ Corte IDH. Caso del Penal Miguel Castro Castro Castro vs Peru, p.109-111.

${ }^{10}$ Ibid.

${ }^{11}$ Ibid. p.83, 97, 103.
} 
no Peru gerou uma concepção dentro da sociedade, onde se entendia que uma mulher estar envolvida nesse tipo de conflito e ser presa por isso. Essa nova percepção sobre a mulher levou os agentes estatais a aplicarem um tratamento mais cruel e violento nas mulheres consideradas suspeitas de terrorismo pelo Estado peruano. $^{12}$

A sentença declarou que a violência de gênero não se reduz à "violência sexual". Determinou-se que houve fatos de violência de gênero específicos contra as prisioneiras, que a violência de gênero atravessou a violência infligida contra as detentas e que o elemento de gênero estava presente em todos os atos violentos. $^{13}$

\subsubsection{Fernández Ortega vs México - 2010 e Rosendo Cantu vs México - 2010}

Os casos tratados a seguir possuem muitas semelhanças no que diz respeito às violações sexuais de mulheres indígenas pelo mesmo Estado e suas sentenças se distanciam por apenas um dia. Desta forma, serão analisados conjuntamente. Em ambos os casos a Corte IDH trouxe novas interpretações e contornos em suas jurisprudências que serão apresentadas logo após os fatos dos casos.

Os casos ocorreram em fevereiro e março de 2002 em um contexto em que havia uma grande presença de militares no estado de Guerrero. O objetivo dos militares era reprimir atividades ilegais, como o crime organizado. A presença de militares nesse local foi controversa no que diz respeito aos direitos e liberdades individuais e comunitárias, deixando a comunidade vulnerável, o que afetou, principalmente, as mulheres. Entre os anos de 1997 e 2004 foram feitas seis denúncias de violação sexual a mulheres indígenas perpetradas por agentes estatais. Porém, em nenhum desses casos houve sanção dos responsáveis. ${ }^{14}$

\footnotetext{
${ }^{12}$ Corte IDH. Caso del Penal Miguel Castro Castro Castro vs Peru, p.64-6.

${ }^{13}$ Ibid. p. 96, 101.

${ }^{14}$ Corte IDH. Caso Rosendo Cantu vs México (2010), p.23-24.; Corte IDH. Caso Fernandez Ortega vs México (2010), p. 28.
} 
No que se refere ao caso Fernández Ortega, a vítima, mulher e indígena, estava em sua casa quando um grupo de militares aproximou-se de sua casa. Três deles entraram, perguntaram para a vítima de onde seu marido havia roubado a carne. Fernandez Ortega não respondeu, pois não sabia falar espanhol e estava com medo. Em seguida, os agentes estatais apontaram a arma para ela, exigiram que se ajoelhasse no chão e a partir de então eles retiraram sua roupa e a estupraram. ${ }^{15}$

A respeito do caso da senhora Rosendo Cantu é necessário frisar que ela é mulher, indígena e criança. Em sua denúncia, a vítima afirmou que estava tomando banho quando oito militares se aproximaram e a cercaram. Dois militares interrogaram-na sobre os "encapuchados", mostraram uma foto e uma lista de nomes, enquanto um dos agentes apontava-lhe uma arma. A vítima disse que não conhecia nenhuma daquelas pessoas. $\mathrm{O}$ militar que estava apontando a arma para Rosendo Cantu bateu em seu estômago, derrubando-a e deixou-a desacordada por alguns segundos. Quando a vítima se recuperou, um agente segurou seu cabelo e insistiu em perguntar se ela conhecia alguma daquelas pessoas enquanto a ameaçava de morte. Em seguida, arranharam seu rosto, tiraram sua saia e sua roupa íntima, jogaram-na no chão e dois militares a estupraram. ${ }^{16}$

Mesmo com todas as dificuldades, como o idioma, sua vulnerabilidade, a distância da comunidade e todos os exames aos quais foi submetida, as senhoras Rosendo Cantu e Fernández Ortega conseguiram denunciar o ocorrido. Porém, o Estado mexicano não realizou uma investigação séria, imparcial e efetiva. ${ }^{17}$

Os casos tratados são de suma importância, pois a Corte Interamericana trouxe novas jurisprudências a respeito da violência sexual. Uma delas foi a de afirmar que a violação sexual é um tipo particular de agressão que, em geral, ocorre em circunstâncias específicas em que estão presentes apenas a vítima e o perpetrador. Devido à natureza desse tipo de violência, não se deve esperar que

\footnotetext{
${ }^{15}$ Corte IDH. Caso Fernandez Ortega vs México (2010), p. 29.

${ }^{16}$ Corte IDH. Caso Rosendo Cantu vs México (2010), p.24-25.

${ }^{17}$ Corte IDH. Caso Rosendo Cantu vs México (2010), p.76-77; Corte IDH. Caso Fernandez Ortega vs México (2010), p. 81-82.
} 
existam provas gráficas ou documentais, e, por isso, a declaração da vítima constitui prova fundamental. ${ }^{18} \mathrm{E}$ o impacto gerado por esse tipo de violência pode fazer com que haja certa imprecisão ao recordá-lo. ${ }^{19}$

Além disso, o Tribunal reafirmou, o já determinado pela Convenção de Belém do Pará, que a violência contra a mulher é uma ofensa à violação da dignidade da pessoa humana e a materialização da histórica relação de poder desigual entre mulheres e homens e que ultrapassa todos os âmbitos da sociedade. $^{20}$

Também foi do entendimento da Corte IDH que a violação sexual é uma forma paradigmática de violência contra as mulheres e que esse tipo de violação ultrapassa a pessoa da vítima, afetando também seus familiares. ${ }^{21}$ Outrossim, foi posto que é próprio da violação sexual o grande sofrimento da vítima, mesmo quando não há lesões ou doenças corporais, pois nem todo caso apresenta esse tipo de evidência. As mulheres vítimas também sofrem graves danos com sequelas psicológicas e até mesmo sociais. ${ }^{22}$

Nas duas sentenças entendeu-se que a vulnerabilidade da vítima e as circunstâncias de estar sendo submetida à violação sexual por agentes estatais e tendo outros assistindo agravou a situação vivida pela vítima e o sofrimento psicológico e moral da mesma. ${ }^{23}$

Diante dessa maior interpretação a respeito da violência contra a mulher, a Corte Interamericana concluiu que a violação sexual pode ser considerada tortura mesmo quando ocorre apenas uma vez e fora de locais estatais. ${ }^{24}$ Para qualificar uma violação sexual como tortura são necessários elementos como a intencionalidade, a severidade do sofrimento e a finalidade do ato. Todos esses requisitos devem ser analisados levando em consideração as circunstâncias

\footnotetext{
${ }^{18}$ Corte IDH. Caso Rosendo Cantu vs México (2010), p.31; Corte IDH. Caso Fernandez Ortega vs México (2010), p. 35.

${ }^{19}$ Corte IDH. Caso Rosendo Cantu vs México (2010), p.32.

${ }^{20}$ Corte IDH. Caso Rosendo Cantu vs México (2010), p.37; Corte IDH. Caso Fernandez Ortega vs México (2010), p. 41

${ }^{21}$ Ibid.

${ }^{22}$ Corte IDH. Caso Rosendo Cantu vs México (2010), p.38.

${ }^{23}$ Corte IDH. Caso Rosendo Cantu vs México (2010), p.38; Corte IDH. Caso Fernandez Ortega vs México (2010), p. 43.

${ }^{24}$ Corte IDH. Caso Rosendo Cantu vs México (2010), p.39; Corte IDH. Caso Fernandez Ortega vs México (2010), p. 39.
} 
específicas do caso concreto. ${ }^{25}$ Ademais, o Tribunal também considerou que a violação sexual é uma violação à vida privada da mulher, pois há uma intromissão na vida sexual e viola o direito da pessoa de tomar uma decisão a respeito de com quem quer ter relações sexuais, escolha mais pessoal e íntima de alguém. $^{26}$

Por fim, a Corte IDH definiu, de forma não exaustiva, algumas das ações que o Estado deve realizar em uma investigação penal a partir de uma denúncia de violência sexual: i) que o depoimento da vítima seja colhido em local cômodo e seguro; ii) que o depoimento seja registrado de forma que não precise ser repetido; iii) que haja atenção médica, sanitária e psicológica para a vítima; iv) que sejam feitos exame psicológico e médico completos e detalhados, que a vítima possa contar com um acompanhante de sua confiança; v) que a investigação seja realizada diligentemente, além da forma de lidar com as possíveis provas; e vi) que seja fornecida gratuidade de justiça à vítima. ${ }^{27}$

\subsubsection{J. vs Peru - 2013 e Espinoza Gonzáles vs Peru - 2014}

Os casos em questão possuem muitas semelhanças em seus fatos e no que diz respeito às violações sexuais. Por esses motivos serão analisados de forma conjunta. Nos dois casos a Corte Interamericana não trouxe novas interpretações, mas reafirmou o que já havia dito em sentenças anteriores fortalecendo sua jurisprudência a respeito da violência contra a mulher perpetrada por agentes estatais, como será demonstrado a seguir.

Os fatos de ambos os casos aconteceram em uma época de conflito entre grupos armados e agentes policiais e militares no Peru, que ocorreu entre os anos 1980 e 2000. ${ }^{28}$ O caso Espinoza Gonzáles vs Peru tratou da detenção ilegal e arbitrária, por ser suspeita de participar de grupo terrorista, de Gladys Carol

\footnotetext{
${ }^{25}$ Corte IDH. Caso Rosendo Cantu vs México (2010), p.44; Corte IDH. Caso Fernandez Ortega vs México (2010), p. 39.

${ }^{26}$ Corte IDH. Caso Rosendo Cantu vs México (2010), p.39-44; Corte IDH. Caso Fernandez Ortega vs México (2010), p. 44.

${ }^{27}$ Corte IDH. Caso Rosendo Cantu vs México (2010), p.63; Corte IDH. Caso Fernandez Ortega vs México (2010), p. 69-70.

${ }^{28}$ Corte IDH. Caso Espinoza Gonzáles vs Peru (2014), p.17; Corte IDH. Caso J. vs Peru (2013), p.19.
} 
Espinoza Gonzáles, em abril de 1993, além da violação sexual e outros atos de tortura dos quais foi vítima enquanto esteve detida na Divisão de Investigação de Seqüestros e da Direção Nacional Contra o Terrorismo. Também trata das condições desumanas e degradantes a que foi submetida entre os anos de $1996 \mathrm{e}$ 2001, como a falta de tratamento médico, alimentação inadequada e incomunicabilidade, e da violência sexual causada em 1999 por agentes estatais. Mesmo após serem denunciados, nenhum dos fatos foi investigado pelo Estado peruano. $^{29}$

O caso J. vs Peru abordou a detenção ilegal e arbitrária, em abril de 1992, por agentes estatais que realizaram tortura e tratamentos cruéis, desumanos e degradantes, além de violação sexual contra a vítima. Esses fatos ocorreram enquanto a senhora J. encontrava-se detida na Direção Nacional Contra o Terrorismo sem qualquer controle judicial e em condições desumanas durante um período de 17 dias. Após ser solta a senhora J. foi absolvida pelo suposto delito de terrorismo e acabou saindo do Peru. Porém, no final do mesmo ano a Corte Suprema anulou a sua absolvição e, por isso, possui até hoje uma ordem de prisão internacional contra ela. ${ }^{30}$

Primeiramente, a Corte IDH utilizou-se de conclusões feitas pela Comissão da Verdade e Reconciliação do Peru $^{31}$ e de sentenças de casos peruanos anteriores ${ }^{32}$ para reafirmar a situação vivida no país e que os casos das senhoras J. e Espinoza Gonzáles estavam inseridos em um contexto de violência de gênero, já que era uma prática generalizada, sistemática e tolerada em determinados casos. ${ }^{33}$

O Tribunal consolida o entendimento de que as vítimas de maus tratos, principalmente quando se encontram detidas no mesmo local onde ocorreu, não

\footnotetext{
${ }^{29}$ Corte IDH. Caso Espinoza Gonzáles vs Peru (2014), p.5.

${ }^{30}$ Corte IDH. Caso J. vs Peru (2013), p.4.

${ }^{31}$ Corte IDH. Caso Espinoza Gonzáles vs Peru (2014), p.17-18; Corte IDH. Caso J. vs Peru (2013), p.18.

${ }^{32}$ Corte IDH. Caso Loayza Tamayo vs Peru (1997); Corte IDH. Caso Penal Miguel Castro Castro Castro vs Peru (2006)

${ }^{33}$ Corte IDH. Caso Espinoza Gonzáles vs Peru (2014), p.21-22;. Corte IDH. Caso J. vs Peru (2013), p.22.
} 
denunciam o ocorrido por medo, e não se pode exigir que elas denunciem todos os atos sofridos em cada oportunidade. ${ }^{34}$

No que diz respeito à violência sexual, a Corte Interamericana continuou com o entendimento de que essa ocorre em circunstâncias específicas não havendo outros tipos de provas, tornando a declaração da vítima uma prova fundamental. E que os depoimentos a respeito desse tipo de violência podem possuir determinada imprecisão. ${ }^{35} \mathrm{O}$ Tribunal continuou com as mesmas definições de violência sexual, podendo inclusive ser realizada sem contato físico $^{36}$, e de violação sexual ${ }^{37}$, e reafirmou que mesmo se não houver qualquer tipo de lesão ou doença essa pode sim ter ocorrido. ${ }^{38}$

A Corte IDH concluiu ainda que o ocorrido com as senhoras J. e Gladis Espinoza Gonzáles fez parte de uma prática generalizada de tortura contra as mulheres que se realizava por meio da violação sexual praticada por agentes estatais. Sendo assim, a violação sexual sofrida pelas vítimas foi considerada tortura. $^{39}$

Ao final da análise a respeito da violência sexual, da violação sexual e da tortura, o Tribunal abordou a questão da prática discriminatória de violência e violação sexual. O mesmo reiterou sua jurisprudência de que em conflitos armados as mulheres e as crianças possuem seus direitos humanos afetados de formas específicas, como por meio da violência sexual, a qual é utilizada como uma forma simbólica de humilhar, castigar e repreender. Em conflitos armados internos, como no caso analisado, a utilização do poder estatal para violar os direitos das mulheres afeta não só a elas, mas possui um efeito na sociedade como um todo. ${ }^{40}$

\footnotetext{
${ }^{34}$ Corte IDH. Caso Espinoza Gonzáles vs Peru (2014), p.57; Corte IDH. Caso J. vs Peru (2013), p.103.

${ }^{35}$ Corte IDH. Caso Espinoza Gonzáles vs Peru (2014), p.57; Corte IDH. Caso J. vs Peru (2013), p.97-98.

${ }^{36}$ Corte IDH. Caso Espinoza Gonzáles vs Peru (2014 p.71; Corte IDH Caso del Penal Miguel Castro Castro Castro vs Peru, p. 105-106; Corte IDH. Caso J. vs Peru (2013), p.110.

${ }^{37}$ Corte IDH. Caso Espinoza Gonzáles vs Peru (2014) p.71-72.; Corte IDH. Caso del Penal Miguel Castro Castro Castro vs Peru, p. 106; Corte IDH. Caso J. vs Peru (2013), p. 110.

${ }^{38}$ Corte IDH. Caso Espinoza Gonzáles vs Peru (2014), p.72; Corte IDH. Caso J. vs Peru (2013), p.106.

${ }^{39}$ Corte IDH. Caso Espinoza Gonzáles vs Peru (2014), par. 195 e 229, p.73 e 82; Corte IDH. Caso J. vs Peru (2013), p. 95.

${ }^{40}$ Corte IDH. Caso Espinoza Gonzáles vs Peru (2014), p. 81-82; Corte IDH. Caso del Penal Miguel Castro Castro Castro vs Peru, p. 79-80.
} 


\subsubsection{Favela Nova Brasília vs Brasil - 2017}

A escolha do Caso Favela Nova Brasília vs Brasil se deu por alguns motivos, como: ser o último caso em que Corte Interamericana tratou da violência contra a mulher perpetrada por agentes estatais; ter ocorrido em um período democrático; e ser um caso brasileiro, sendo possível uma análise comparativa ainda maior com o relatório da CNV.

Os fatos do caso analisado se referem aos problemas na investigação e sanção dos responsáveis pelas execuções extrajudiciais de 26 pessoas durante as operações da Polícia Civil do Rio de Janeiro nos dias 18 de outubro de 1994 e 8 de maio de 1995 na Favela Nova Brasília. A polícia justificou as mortes como "autos de resistência". Além disso, duas meninas e uma mulher (J.F.C, C.S.S. e L.R.J.) foram vítimas de tortura e violência sexual por parte dos policiais. Por fim, as investigações foram realizadas com o objetivo de revitimizar para apontar sua culpa e não com o intuito de analisar a legitimidade do uso da força. ${ }^{41}$

O caso trata também da violência sexual sofrida por J.F.C., C.S.S. e L.R.J. O Estado brasileiro não poderia ser condenado por esses atos apenas, pois estes ocorreram antes de 10 de dezembro de 1998, data em que o Brasil reconheceu a competência da Corte IDH. ${ }^{42}$ Desta forma, o Tribunal analisou os fatos ocorridos para que pudesse, a partir deles, afirmar se o Estado havia ou não cumprido com seu dever de respeitar as garantias judiciais e a proteção judicial às vítimas. Por isso, na sentença, a Corte Interamericana traz, dentro da análise das garantias judiciais e da proteção judicial, dois itens chamados: "normas relativas à devida diligência e prazo razoável em casos de alegada violência sexual" ${ }^{43}$ e "a devida diligência e a proteção judicial referentes à violência sexual contra L.R.J., C.S.S. e J.F.C." ${ }^{44}$

A sentença não trouxe novidades, mas seguiu reafirmando a jurisprudência de casos anteriores. Em um primeiro momento a Corte IDH

\footnotetext{
${ }^{41}$ Corte IDH. Caso Favela Nova Brasília vs Brasil (2017), p.3.

${ }^{42}$ Ibid. p. 15-16

${ }^{43}$ Ibid. p. 61-64

${ }^{44}$ Ibid. p. 65
} 
afirmou que os Estados devem contar com um marco jurídico de proteção, que seja efetivo e que existam políticas de prevenção e práticas que facilitem a atuação eficaz perante as denúncias. ${ }^{45}$ Além disso, os Estados devem realizar medidas que previnam violações específicas em casos em que é sabido que mulheres e crianças podem ser vítimas de violência. ${ }^{46} \mathrm{O}$ Tribunal enfatizou que além das obrigações da CADH os Estados possuem obrigações específicas com relação às mulheres previstas na Convenção de Belém do Pará. ${ }^{47}$

Ademais, consta na sentença as definições de violência sexual ${ }^{48}$ e violação sexual ${ }^{49}$, que serão melhor explicitadas a seguir, além de suas especificidades, como a de ser uma violação que ultrapassa a pessoa da vítima ${ }^{50}$. Além disso, reafirma que a violação sexual é uma forma de tortura. ${ }^{51}$ A Corte Interamericana ainda dá ênfase ao que está previsto no preâmbulo da Convenção de Belém do Pará de que a violência contra a mulher é uma ofensa à dignidade humana e uma manifestação das relações desiguais de poder entre homens e mulheres e que esta ultrapassa todos os âmbitos da sociedade. ${ }^{52}$

Como estava sendo analisado o dever de devida diligência do Estado brasileiro, a sentença apresentou os sete itens, já enumerados anteriormente, que o Estado deve realizar em casos de violência contra a mulher, como por exemplo: garantir atenção médica e psicológica à vítima, que esta seja acompanhada de alguém de sua confiança quando for realizar os exames médicos, entre outros. ${ }^{53}$

\footnotetext{
${ }^{45}$ Corte IDH. Caso Favela Nova Brasília vs Brasil (2017), p.61.; Corte IDH. Caso Gonzalez y otras (Campo Algodonero) vs México (2009), p. 69.

${ }^{46}$ Ibid

${ }^{47}$ Corte IDH. Caso Favela Nova Brasília vs Brasil (2017), par. 243; Corte IDH. Caso Rosendo Cantu vs México (2010), p. 37, par. 108; Corte IDH. Caso Fernandez Ortega vs México (2010), p.41, par. 118.

${ }^{48}$ Corte IDH. Caso Favela Nova Brasília vs Brasil (2017), p.62; Corte IDH. Caso J. vs Peru (2013), par. 358

${ }^{49}$ Corte IDH. Caso Favela Nova Brasília vs Brasil (2017), p.62, Corte IDH. Caso del Penal Miguel Castro Castro Castro vs Peru, p. 106, par. 310; Corte IDH. Caso J. vs Peru (2013), par. 359.

${ }^{50}$ Corte IDH. Caso Favela Nova Brasília vs Brasil (2017), p.62; Corte IDH. Caso Fernandez Ortega vs México (2010), p.41, par. 119.

${ }^{51}$ Corte IDH. Caso Favela Nova Brasília vs Brasil (2017), p.63, Corte IDH. Caso del Penal Miguel Castro Castro Castro vs Peru, p. 149, par. 448-450.

${ }^{52}$ Corte IDH. Caso Favela Nova Brasília vs Brasil (2017), p.62.

${ }^{53}$ Corte IDH. Caso Favela Nova Brasília vs Brasil (2017), p.64; Corte IDH. Caso Rosendo Cantu vs México (2010), p. 63.
} 
No final, o Tribunal reconheceu que a violação de uma mulher sob custódia de agentes estatais é um ato muito grave, tendo em vista a vulnerabilidade da vítima. E que a violação sexual é uma experiência traumática que pode levar a danos físicos e psicológicos irreversíveis, o que a torna diferente de outras situações traumáticas. ${ }^{54}$

\subsection{Definições}

\subsubsection{Violência de Gênero}

Conforme entendimento da Corte IDH, a violência baseada no gênero, ou seja, a violência dirigida à mulher por ser mulher ou a violência que afeta a mulher de forma desproporcional, é uma forma grave de discriminação. Essa é considerada uma das formas mais extremas e generalizadas, que impede e nulifica de forma severa o exercício dos direitos das mulheres e impede que elas gozem de direitos e liberdades da mesma forma que os homens. ${ }^{55}$ A Corte Interamericana faz referência a Tratados internacionais, como a CEDAW preâmbulo $^{56}$ - e a Convenção de Belém do Pará - preâmbulo e artigo $6^{57}$-, para identificar uma relação entre a violência contra a mulher e a sua discriminação.

A Recomendação Geral nº 19 da CEDAW traz o entendimento de que esse tipo de discriminação inclui a violência baseada no sexo, ou seja, é a violência dirigida contra a mulher por ser mulher e esta é atingida de forma desproporcional. Esse tipo de violência engloba atos que acarretem danos ou sofrimentos de caráter físico, mental, psicológico ou sexual, além de ameaças de

\footnotetext{
${ }^{54}$ Corte IDH. Caso Favela Nova Brasília vs Brasil (2017), p.63, Corte IDH. Caso del Penal Miguel Castro vs Peru, p. 65, p. 106-107.

${ }^{55}$ Corte IDH. Caso Gonzalez y otras (Campo Algodonero) vs México (2009), p. 101; Corte IDH. Caso Rosendo Cantu vs México (2010), p. 80; Corte IDH. Caso Espinoza Gonzáles vs Peru (2014), p.80.

${ }^{56} \mathrm{ONU}$. Convenção sobre a eliminação de todas as formas de discriminação contra a mulher. Disponível em: http://www.onumulheres.org.br/wp-content/uploads/2013/03/convencao_cedaw1.pdf, Acesso em: 05 nov. 2018.

${ }^{57}$ OEA. Convenção Interamericana para a Prevenção, Punição e Erradicação da Violência contra a Mulher ("Convenção de Belém do Pará"), 1994. Disponível em: http://www.cidh.org/basicos/portugues/m.belem.do.para.htm. Acesso em: 05 nov. 2018.
} 
que esses atos sejam realizados, haja coação e outras formas de liberdade. ${ }^{58}$ No Caso Penal Miguel Castro Castro vs Peru o Tribunal utilizou o conceito de violência contra a mulher apresentado. Esse foi o primeiro caso analisado com a perspectiva de gênero. ${ }^{59}$

A Convenção de Belém do Pará abrange não só o entendimento presente no documento citado anteriormente, como desenvolve a concepção de que mesmo que a violência tenha ocorrido em âmbito privado, como no âmbito familiar, escolar, policial, estatal, sob detenção judicial, entre outros, esta continua sendo uma violação aos direitos humanos das mulheres. Desta forma, não se pode mais alegar que dita violência ocorreu em âmbito privado. ${ }^{60}$

Cabe ressaltar que a jurisprudência firmada pelo Tribunal a respeito do artigo 1.1 da $\mathrm{CADH}$, que dispõe sobre a obrigação dos Estados Partes de respeitar e garantir o pleno e livre exercício dos direitos e liberdades presentes no Tratado sem qualquer discriminação, determina que existe uma relação direta entre a obrigação de respeitar e garantir os direitos humanos e o princípio da igualdade e não discriminação. ${ }^{61}$

A Corte Interamericana vai além dos instrumentos internacionais ao afirmar que a ineficácia judicial com relação a casos de violência contra as mulheres favorece um ambiente de impunidade, facilitando e promovendo a reincidência da violência contra a mulher, dando a entender que esse tipo de violência pode ser tolerado e aceito pela sociedade. Esse hostil ambiente acarreta uma sensação de insegurança para as mulheres, pois, muitas vezes, quando há indícios de violência contra a mulher não são realizadas medidas necessárias que levem a uma investigação e um processo judicial. Desta forma, gera desconfiança

\footnotetext{
${ }^{58}$ ONU. Convenção sobre a eliminação de todas as formas de discriminação contra a mulher. Recomendação $n^{\circ} 19$

${ }_{59}$ Corte IDH. Caso del Penal Miguel Castro Castro vs Peru (2006), p.79

${ }^{60}$ OEA. Convenção de Belém do Pará. Disponível em: http://www.cidh.org/basicos/portugues/m.belem.do.para.htm Acesso em: 05 nov. 2018; CLÉRICO, Laura.; NOVELLI, Celestre. La Violencia contra las mujeres en las procucciones de la comisión y la Corte Interamericana de Derechos Humanos. Estudios Consitucionales, Año 12, nº 1. 2014. p. 15-70.

${ }^{61}$ Corte IDH. Caso Gonzalez y otras (Campo Algodonero) vs México (2009), p. 101; Corte IDH. Caso Espinoza Gonzáles vs Peru (2014), p.81; Corte IDH. Veliz Franco vs Gratemala (2014), par.204.
} 
com relação ao sistema judiciário e pode, por si só, constituir uma forma de discriminação baseada no gênero. ${ }^{62}$

O Tribunal demonstra ainda a forte ligação entre os problemas da discriminação e da violência contra as mulheres. ${ }^{63}$ Levou-se em consideração que a discriminação trata da permanência, da difusão e reprodução dos estereótipos de gênero, que "implica em uma distribuição e direitos a favor do homem e em detrimento da mulher". ${ }^{64}$

\subsubsection{Violência Sexual e Violação Sexual}

Atualmente a Corte IDH já possui entendimento reiterado do conceito de violência sexual. Desde o Caso Penal Miguel Castro Castro vs Peru (2006) até o Caso Favela Nova Brasília vs Brasil (2017), o Tribunal entendeu que violência sexual são ações de natureza sexual que se comete contra uma pessoa sem seu consentimento. A violência pode incluir a invasão física do corpo humano ou ato que não envolva penetração ou contato físico. ${ }^{65}$

Em relação à definição de violação sexual, a Corte Interamericana estabelece que essa não implica, necessariamente, uma relação sexual sem consentimento por via vaginal. Pode-se configurar também com atos de penetração vaginal ou anal, sem consentimento da vítima, através da utilização de outras partes do corpo do agressor ou objetos, bem como a penetração oral do membro viril do corpo do agressor. Tão somente uma penetração, por menor que seja, é o suficiente para que se configure a violação sexual. Destaca-se que esta é um tipo de violência sexual. ${ }^{66}$

\footnotetext{
${ }^{62}$ Corte IDH. Veliz Franco vs Gratemala (2014), pg. 80.

${ }^{63}$ CLÉRICO, Laura.; NOVELLI, Celestre. La Violencia contra las mujeres en las procucciones de la comisión y la Corte Interamericana de Derechos Humanos. Estudios Consitucionales, Año 12, nº1. 2014. p. 67.

${ }^{64}$ Ibid. 69

${ }^{65}$ Corte IDH. Caso del Penal Miguel Castro Castro vs Peru. (2006), p. 105-106; Corte IDH. Caso Fernandez Ortega vs México (2010), p.41; Corte IDH. Caso Rosendo Cantu vs México (2010), p. 37; Corte IDH. Caso J. vs Peru (2013), par. 358, p.110; Corte IDH. Caso Favela Nova Brasília vs Brasil (2017), p.62.

${ }^{66}$ Corte IDH. Caso del Penal Miguel Castro Castro vs Peru. (2006), p. 106; Corte IDH. Caso Fernandez Ortega vs México (2010), p.41, par. 119; Corte IDH. Caso Rosendo Cantu vs México (2010), p. 37; Corte IDH. Caso J. vs Peru (2013), p.110; Corte IDH. Caso Favela Nova Brasília vs Brasil (2017), p.62-63.
} 
Ademais, no Caso Fernández Ortega vs México, o Tribunal entendeu que para que seja configurada a violação sexual não é necessário que haja resistência física à agressão. E a presença de uma conduta com elementos coercitivos é o suficiente para considerar que houve a violação. ${ }^{67}$

\subsubsection{Violência Sistemática Contra a Mulher}

A Corte IDH nunca chegou a definir especificamente o que seria a violência sistemática contra a mulher, apesar de ter tido a oportunidade em casos como os analisados anteriormente em que foi afirmado que havia uma prática sistemática de violações de direitos humanos. No entanto, se utilizou do termo em sentenças de casos, como, por exemplo, no Gonzáles e outras (Campo Algodoeiro) vs México ${ }^{68}$ e Espinoza Gonzáles vs Peru ${ }^{69}$.

No Sistema Interamericano de Direitos Humanos a Comissão IDH que mais se aproximou da definição do que seria a violência sistemática contra a mulher no caso 12.051 - Maria da Penha Maia Fernandes. No relatório a Comissão Interamericana afirma que a falta de julgamento e condenação do agressor da senhora Maria da Penha, nesse caso, fomentou a tolerância por parte do Estado brasileiro. Foi demonstrado também que essa tolerância estatal não foi apenas nesse caso, mas é uma tolerância de todo o sistema estatal. Ou seja, é uma violência sistemática. E esse tipo de complacência faz com que se perpetuem as raízes e elementos psicológicos, sociais e históricos que sustentam a violência contra a mulher. ${ }^{70}$

\subsubsection{Violação Sexual Perpetrada por Agente Estatal - Tortura}

Durante muitos anos a Corte Interamericana julgou os casos sem uma abordagem de gênero, não levando em consideração as especificidades das violações ocorridas contra mulheres em situações de conflito armado ou detidas.

\footnotetext{
${ }^{67}$ Corte IDH. Caso Fernandez Ortega vs México (2010), p.40.

${ }^{68}$ Corte IDH. Caso Gonzalez y otras (Campo Algodonero) vs México (2009), pg. 94-95.

${ }^{69}$ Corte IDH. Caso Espinoza Gonzáles vs Peru (2014), p.63,68.

${ }^{70}$ Comissão IDH, Relatório $N^{\circ}$ 54/01 Caso 12.051, Maria da Penha Maia Fernandes, 4 de abril de 2001, par. 55. Disponível em: https://cidh.oas.org/annualrep/2000port/12051.htm Acesso em: 07 nov. 2018.
} 
Nos casos Caballero Delgado y Santana vs Colômbia (1995), Loayza Tamayo vs Peru (1997) e Maritza Urrutia vs Guatemala (2003) o Tribunal não tratou da violência de gênero, mesmo as vítimas alegando terem sofrido nudez forçada e violação sexual. Apenas em 2006 houve a primeira sentença com abordagem de gênero, que foi o caso Penal Miguel Castro Castro vs Peru.

Para tratar da violência sexual como tortura, primeiramente é necessário definir o que é tortura, tendo em vista que já foi apresentada a definição de violação sexual. A Convenção Interamericana para Prevenir e Punir a Tortura define, em seu artigo 2, o ato como tortura quando estão presentes três requisitos: a) ato realizado intencionalmente pelo qual se inflija a uma pessoa penas ou sofrimentos físicos ou mentais; b) cometido com um objetivo; e c) por um agente estatal. $^{71}$

No caso Penal Miguel Castro Castro vs Peru, a Corte IDH afirmou que a violação sexual cometida por agente estatal contra uma mulher detida é um ato extremamente grave e reprovável, levando em consideração a vulnerabilidade da vítima e o abuso de poder do agente. ${ }^{72}$

Em 2010, ao julgar os casos Fernández Ortega vs México e Rosendo Cantu vs México, a Corte Interamericana avançou em seu entendimento ao considerar a violação sexual como tortura. Além de outros grandes avanços jurisprudenciais que serão tratados na análise dos casos.

No entanto, cabe salientar que no caso Gonzalez e outras (Campo Algodoeiro) vs México (2009) a juíza Cecilia Medina Quiroga em seu voto apresentou uma interpretação mais ampla a respeito do que deve ser considerado tortura. ${ }^{73}$ Em seu voto, a juíza ${ }^{74}$ criticou a Corte IDH por restringir a classificação de tortura apenas a atos em que houve participação por ação ou omissão de agentes estatais. Quiroga entende que a diferença entre a tortura e o tratamento cruel, desumano e degradante não está no fato de haver participação estatal ou

\footnotetext{
${ }^{71}$ OEA. Convenção Interamericana para Prevenir e Punir a Tortura, art.2, 1985.

${ }^{72}$ Corte IDH. Caso del Penal Miguel Castro Castro vs Peru. (2006), p.106

${ }^{73}$ Voto Concorrente da Juíza Cecilia Medina Quiroga em relação à Sentença da Corte Interamericana de Direitos Humanos no Caso González e outras ("Campo Algodoeiro") vs México, de 16 de Novembro de 2009

${ }^{74}$ Ibid. parágrafo. 16 e 17
} 
não, mas na gravidade e intensidade do sofrimento físico e psicológico para a vítima. ${ }^{75}$ Cecilia Medina Quiroca afirmou que a Corte Interamericana é independente e pode utilizar-se de outros sistemas internacionais para entender o que seria tortura ${ }^{76}$, indo mais além do que a Convenção Interamericana para Prevenir e Punir a Tortura ${ }^{77}$ e a Convenção Contra a Tortura ${ }^{78}$ definiram, como fizeram outras cortes, como o Tribunal Europeu ${ }^{79}$ e o Tribunal para a Antiga Iugoslávia ${ }^{80}$.

A Corte IDH mantém o entendimento de que é necessária a participação de agente estatal, por ação ou omissão, para constituir tortura em sentenças posteriores como nos Casos, J. vs Peru (2013), Espinoza Gonzáles vs Peru (2014), Favela Nova Brsília vs Brasil (2017).

\footnotetext{
${ }^{75}$ Voto Concorrente da Juíza Cecilia Medina Quiroga em relação à Sentença da Corte Interamericana de Direitos Humanos no Caso González e outras ("Campo Algodoeiro") vs México, de 16 de Novembro de 2009, parágrafo. $7,8,9$

${ }^{76}$ Ibid. parágrafo. 17

${ }^{77}$ OEA. Convenção Interamericana para Prevenir e Punir a Tortura, art.3, 1985

${ }^{78}$ ONU. Convenção contra a Tortura e outros Tratamentos Cruéis, Desumanos ou Degradantes, art.1

${ }^{79}$ Corte IDH. Voto Concorrente da Juíza Cecilia Medina Quiroga em relação à Sentença da Corte Interamericana de Direitos Humanos no Caso González e outras ("Campo Algodoeiro") vs México, de 16 de Novembro de 2009, parágrafo. 6

${ }^{80}$ Ibid. 14
} 


\section{Capítulo 2 - Comissão Nacional da Verdade: Violência de Gênero e Violência Sexual}

Entre 1964 e 1985 o Brasil viveu sob o regime de uma ditadura militar, com uma sucessão de generais do exército ocupando a presidência da República. A ditadura foi o resultado de um longo processo dentro da história do regime republicano brasileiro. Após uma ditadura nos moldes fascistas, o Estado Novo, de 1937 a 1945, a sociedade brasileira conheceu um período de redemocratização, com a elaboração de uma nova constituição, de 1946. Eleito presidente em 1950, Vargas governou com uma orientação mais nacionalista, voltada para interesses da classe trabalhadora, o que levou a uma indisposição com as oligarquias e os interesses internacionais no país.

A crise imediata que levou à ditadura de 1964-1985 se iniciou em 1961 com a renúncia do presidente Jânio Quadros e a posse do vice-presidente João Goulart, ex-ministro do Trabalho de Getúlio Vargas. Eleito pelo voto direto, Goulart foi impedido de tomar posse, criando-se o sistema de parlamentarismo. Em janeiro de 1963, após um movimento pela legalidade, o Brasil voltou a ser presidencialista e Jango, como era conhecido o presidente, assume o cargo.

João Goulart foi derrubado por um golpe militar em 31 de março de 1964, com apoio das classes mais conservadoras. O Congresso nacional, já sem muitos deputados que tiveram seus mandatos suspensos, elegeu presidente o marechal Castelo Branco. A promessa era o respeito a constituição de 1946, de entrega do cargo ao sucessor em 1965 e a garantia de que as cassações de mandatos tinham terminado.

Castelo Branco ficou até 1967 e em 1968 foi realizado Ato Institucional no 5. Com 12 artigos, o documento vinha acompanhado do Ato Complementar $\mathrm{n}^{\mathbf{o}} 38$ que fechava o Congresso Nacional por tempo indeterminado. A ditadura militar esforçou-se para enquadrar seus atos arbitrários em um arcabouço jurídico e constituir um tipo de legalidade de exceção. 
Durante o contexto da ditadura militar, inúmeras violações de direitos humanos ocorreram como prisões arbitrárias, torturas, desaparecimentos forçados e sem qualquer tipo de sanção aos agentes estatais que as perpetravam.

Com o intuito de conhecer a história do país para que esse tipo de regime autoritário não voltasse a ocorrer, nem violações de direitos humanos desse tipo, entendeu-se necessária a criação de uma comissão da verdade para investigar os acontecimentos do período, assim como ocorreu no Chile, na Argentina, no Peru. Apesar da Comissão Nacional da Verdade ter sido criada muito anos depois da volta da democracia no país.

A Comissão Nacional da Verdade foi instaurada no Brasil pela lei 12.528 de 18 de novembro de $2011^{81}$. A CNV foi criada para efetivar o direito à memória e à verdade histórica e promover a reconciliação nacional. No artigo $3^{\circ}$ da lei estão presentes os objetivos e no artigo $4^{\circ}$ estão os poderes que a $\mathrm{CNV}$ possuiu para que ela realizasse seus objetivos. Dentre os objetivos previstos na lei estão: a) esclarecer os fatos e as circunstâncias dos casos de graves violações de direitos humanos praticadas entre os anos de 1946 e $1988^{82}$; b) proporcionar o esclarecimento detalhado dos casos de torturas, mortes, desaparecimentos forçados, ocultação de cadáveres e sua autoria ${ }^{83}$; c) recomendar medidas e políticas públicas a serem adotadas para prevenir a violação de direitos humanos, assegurando sua não repetição e promovendo a efetiva reconciliação nacional ${ }^{84}$. No artigo 11 está definido o tempo de sua atuação, inicialmente de dois anos e depois prorrogado até o dia 16 dezembro de 2014. No mesmo artigo também está prevista a obrigação de apresentar um relatório que contivesse as atividades realizadas, os fatos examinados, as suas conclusões e as recomendações ${ }^{85}$.

$\mathrm{O}$ relatório final da $\mathrm{CNV}$ ficou dividido em três volumes. O Volume I é formado por um texto único, composto por três partes divididas em 18 capítulos

\footnotetext{
${ }^{81}$ BRASIL. Lei $n^{\circ} 12.528$, de 18 de novembro de 2011. Cria a Comissão Nacional da Verdade no âmbito da Casa Civil da Presidência da República. Disponível em: http://www2.camara.leg.br/legin/fed/lei/2011/lei-12528-18-novembro-2011-611803-normaatualizadapl.pdf. Acesso 18 nov. 2018.

${ }^{82}$ Ibid. art. $3^{\circ}, \mathrm{I}$

${ }^{83}$ Ibid. art. $3^{\circ}$, II

${ }^{84}$ Ibid. art. $3^{\mathrm{o}}$, VI

${ }^{85}$ Ibid. art. 11
} 
e no último estão presentes as conclusões e recomendações feitas pela Comissão. O Volume II possui textos independentes, feitos por diferentes grupos de, assinados individualmente pelos membros da $\mathrm{CNV}$, e que tratam de outras temáticas. Por fim, o Volume III é formado pelos perfis dos 434 mortos e desaparecidos políticos.

\subsection{A Dimensão Sexual e de Gênero da Tortura}

A CNV criou Grupos de Trabalhos para tratarem de temas específicos e um deles é o GT Ditadura e Gênero, coordenado por Paulo Sérgio Pinheiro (membro e conselheiro) e por Glenda Mezarobda (pesquisadora). Essa divisão tinha como objetivo descentralizar as investigações e garantir uma autonomia aos pesquisadores. ${ }^{86} \mathrm{O}$ Grupo de Trabalho buscou pesquisar a violência contra a mulher, suas consequências e impactos. Além disso, procurou dar visibilidade ao sofrimento das mulheres envolvidas no conflito e àquelas cujas famílias foram perseguidas por questões políticas, tiveram mortos ou desaparecidos. ${ }^{87} \mathrm{O}$ GT Ditadura e Gênero possuía os seguintes objetivos: i) dar visibilidade ao sofrimento das mulheres afetadas pela ditadura, seja aquelas que se engajaram em movimentos de resistência ou que tiveram familiares vitimados pela repressão; ii) considerar a carga extra que foi imposta às mulheres pela ditadura; iii) "incorporar transversalmente a questão de gênero" ao relatório final; iv) "detectar eventual persistência de padrões ou arranjos institucionais que continuem permitindo" a violência contra as mulheres; v) inserir no relatório final "recomendações que propiciem a não-repetição de tais crimes". ${ }^{88}$ Esse Grupo de Trabalho que ficou responsável, principalmente, pela elaboração do "Capítulo 10 - Violência Sexual, Violência de Gênero e Violência Contra Crianças e Adolescentes".

\footnotetext{
${ }^{86}$ BRASIL. Comissão Nacional da Verdade. Relatório, volume 1. Brasília: CNV, 2014, p.51. Disponível em: http://cnv.memoriasreveladas.gov.br/images/pdf/relatorio/volume_1_digital.pdf Acesso em: 05 nov. 2018.

${ }^{87}$ Disponível em: http://www.cnv.gov.br/16-grupos-de-trabalho/26-ditadurae-genero.html . Acesso em 15 out. de 2018.

${ }^{88}$ CNV, Reunião ampla. GT Ditadura e Gênero. Coordenação: Paulo Sérgio Pinheiro. Disponível em: http://www.cnv.gov.br/images/pdf/grupos_trabalho/CNV_REUNIAO_AMPLA_Genero_250313.pdf . Acesso em 15 de outubro de 2018.
} 
Para tratar da dimensão sexual e de gênero da tortura é necessário fazer uma leitura conjunta do "Capítulo 7, "Quadro conceitual das graves violações", no qual a $\mathrm{CNV}$ trouxe as definições de tortura e suas derivações. A CNV, considerando a normativa internacional ${ }^{89}$, determinou que um ato de tortura consiste: 1) na ação ou omissão intencional de agente do Estado ou terceiro que atue com o consentimento estatal; 2) sofrimento, aflição física ou psíquica infligida à vítima, ou diminuição de sua capacidade física ou mental; 3) um fim qualquer que motive a tortura. ${ }^{90}$ No contexto brasileiro, as principais situações caracterizadoras de tortura foram: tortura em caso de detenção/prisão; em caso de violência sexual; infligida aos familiares das vítimas das graves violações de direitos humanos; praticada por funcionários públicos. ${ }^{91}$

No que se refere à tortura nos casos de violência sexual, a CNV definiu que esse tipo de tortura configura-se como:

"atos de natureza sexual cometidos contra uma pessoa sem seu consentimento. Abrange tanto a violação física do corpo humano - a penetração vaginal, anal ou oral, com partes do corpo do agressor ou com objetos - como os atos que não imponham penetração ou sequer contato físico, como o desnudamento forçado e a revista íntima. Estaria aí contemplado também o uso de animais nas genitálias, (...)”92

Ao abordar esse tipo de violação, a CNV utilizou a normativa e jurisprudência internacional, como a Convenção de Belém do Pará, o Estatuto de Roma e os julgamentos do Tribunal Penal Internacional para ex Iuguslávia e para Ruanda. Para além da tortura, a violência sexual, nos casos em que esse tipo de violência ocorre de forma generalizada ou sistemática a violência sexual faz parte da categoria de crimes contra a humanidade. No caso brasileiro, a CNV entendeu que como a violência sexual era usada por agentes estatais para, entre outros motivos, anular a personalidade da vítima, pode-se considerar que houve sim crime contra a humanidade no Brasil no período da ditadura militar. ${ }^{93}$

\footnotetext{
${ }^{89}$ BRASIL. Comissão Nacional da Verdade. Relatório, volume 1. Brasília: CNV, 2014, p.283-285. Disponível em: http://cnv.memoriasreveladas.gov.br/images/pdf/relatorio/volume_1_digital.pdf Acesso em: 05 nov. 2018.

${ }^{90}$ Ibid. p. $284-285$

${ }^{91}$ Ibid. p. $285-287$

${ }^{92}$ Ibid. p. 286

${ }^{93}$ Ibid.
} 
No capítulo intitulado "Tortura", ficou comprovado pela CNV que a partir do golpe militar, de 1964, a prática sistemática de tortura foi adotada como política de Estado. Apesar de a sistematização da tortura ter sido oficialmente negada durante a ditadura militar ou qualificada como "abusos", "excessos" ou "situações fora de controle", conforme depoimentos colhidos pela CNV de agentes da repressão ${ }^{94}$ e de vítimas e documentos.

Sobre a institucionalização da tortura como política de Estado, a CNV apontou que os torturadores eram premiados pelo governo ditatorial militar através da entrega da "Medalha do Pacificador" e que as autoridades do período se negavam a investigar a prática de tortura por parte do Estado, afirmando haver uma campanha de difamação do Brasil no exterior. Existia, na época, a doutrina da segurança nacional que abrangia a ideia de integridade do território, proteção do povo e preservação dos interesses nacionais contra qualquer tipo de ameaça e agressão. Com isso, o combate à guerra revolucionária e à expansão do comunismo, justificava-se toda forma de opressão contra o inimigo interno. Nesse contexto, foi editado o Ato Institucional n5 de 1968.

A CNV, por fim, destacou o documento oficial do Terceiro Programa Nacional de Direitos Humanos, de 2010, da Secretaria de Direitos Humanos da Presidência da República, no qual estima-se que cerca de 20 mil brasileiros tenham sofrido tortura durante a ditadura militar. A CNV fez uso de fontes disponíveis, mas estima-se que os números apresentados são inferiores ao número real de torturados.

A tortura passou a ser sistematicamente empregada pelo Estado brasileiro desde o golpe de 1964, seja como método de coleta de informações ou obtenção de confissões, seja como forma de disseminar o medo. Deixou de se restringir aos métodos violentos já empregados pela polícia no Brasil contra presos comuns para tornar-se a essência do sistema militar de repressão política, baseada nos argumentos da supremacia da segurança nacional e da existência de uma guerra

\footnotetext{
${ }^{94}$ Os depoimentos de Marival Chaves Dias do Canto, ex-analista do DOI-CODI do II Exército de São Paulo e do ex-delegado do DOPS, do Espírito Santo, Claudio Guerra, prestados à CNV são dois exemplos.
} 
contra o "terrorismo". Foi usada com regularidade por diversos órgãos da estrutura repressiva, entre delegacias e estabelecimentos militares, bem como em estabelecimentos clandestinos em diferentes espaços do território nacional.

No início do capítulo 10 a CNV traz o conceito de gênero utilizado durante o mesmo. Entendeu-se que quando se trata de gênero quer dizer que estão se referindo aos "comportamentos, atributos, características pessoais e expectativas associadas ao sexo biológico de uma pessoa por determinada cultura, sendo construído e aprendido durante o processo de socialização" ${ }^{95}$. Assim, gênero é a combinação de determinantes biológicas e culturais, sendo construído a partir de especificidades ligadas ao tempo e ao contexto em que se insere.

As relações baseadas no gênero acabam por impor normas do feminino e do masculino. Essas relações sociais distinguem as pessoas, sendo a masculinidade e a feminilidade definidas conforme o papel esperado do homem e da mulher, respectivamente, na sociedade. Como existe o predomínio da masculinidade, existe um desequilíbrio nas relações de gênero. E estas envolvem muitas formas de coerção e fazem parte do que constitui as relações de dominação de gênero.

Para tratar da violência contra a mulher, a CNV usou diferentes normativas internacionais, além das já citadas anteriormente, quando foi abordado o capítulo 7 do relatório. Primeiramente, como uma introdução histórica, foi utilizada a Carta da ONU (1945) e a Declaração Universal dos Direitos Humanos (1948) para reafirmar que todos são iguais perante a lei e que todos devem ser respeitados independentemente de suas diferenças. ${ }^{96}$ Em seguida usou o artigo $\mathrm{n}^{\circ} 5$ da Convenção Americana de Direitos Humanos para deixar claro que: "Ninguém deve ser submetido a torturas, nem penas ou tratos cruéis,

\footnotetext{
95 BRASIL. Comissão Nacional da Verdade. Relatório, volume 1. Brasília: CNV, 2014, p. 401. Disponível em: http://cnv.memoriasreveladas.gov.br/images/pdf/relatorio/volume_1_digital.pdf Acesso em: 05 nov. 2018.

${ }^{96}$ Ibid. p. 416.
} 
desumanos ou degradantes. Toda pessoa privada da liberdade deve ser tratada com o respeito devido e à dignidade inerente ao ser humano." 97

Tratando especificamente da discriminação da mulher, a CNV apontou a Convenção sobre a Eliminação de Todas as Formas de Discriminação contra a Mulher (CEDAW - 1979), que foi o primeiro tratado internacional que tratou do tema de forma autônoma. A mesma também foi utilizada pela Corte IDH em seus casos quando abordou a violência de gênero, como foi tratado no capítulo 1. Ainda com relação à CEDAW, foi abordada a recomendação $\mathrm{n}^{\circ} 18$, pois foi ela que trouxe a definição de "discriminação contra a mulher", que inclui a violência baseada em diferenças de gênero e que é manifestada através de atos que gera danos físicos, mentais ou sexuais. ${ }^{98}$

Ainda sobre a normativa internacional e seu histórico, a CNV referiu-se a Plataforma de Ação de Viena, em 1993, pela qual os Estados explicitaram a ideia de que a violência contra a mulher está inserida em uma violação de direitos humanos, já que os direitos das mulheres são direitos humanos. ${ }^{99} \mathrm{Em}$ consequência, a Declaração sobre a eliminação da violência contra as mulheres definiu a "violência contra as mulheres" como:

"qualquer ato de violência baseado no gênero do qual resulte, ou possa resultar, dano ou sofrimento físico, sexual ou psicológico para as mulheres, incluindo as ameaças de tais atos, a coação ou a privação arbitrária de liberdade, que ocorra, quer na vida pública, quer na vida privada."

A CNV cita o Sistema Interamericano de Direitos Humanos ao tratar da Convenção de Belém do Pará (1994) afirmando que esta definiu a violência

\footnotetext{
${ }^{97}$ Organização dos Estados Americanos. Convenção Americana de Direitos Humanos ("Pacto de San José de Costa Rica"), 1969, art.5. Disponível em: https://www.cidh.oas.org/basicos/portugues/c.convencao_americana.htm. Acesso em: 05 nov. 2018.

98 BRASIL. Comissão Nacional da Verdade. Relatório, volume 1. Brasília: CNV, 2014, p.416. Disponível em: http://cnv.memoriasreveladas.gov.br/images/pdf/relatorio/volume_1_digital.pdf Acesso em: 05 nov. 2018.

${ }_{99}$ Ibid.

${ }^{100}$ Ibid. p. 417
} 
contra a mulher no sistema regional. E que a violência contra a mulher, além de física e psicológica, também inclui a violência sexual. ${ }^{101}$

No sistema mundial houve ainda a Plataforma de Ação de Pequim (1995) onde se reiterou que é necessário que sejam realizados todos os esforços necessários para proteger a mulher e garantir que haja investigação, processo e punição dos responsáveis por crimes contra as mulheres. ${ }^{102}$

A CNV trouxe Tribunais Internacionais para demonstrar de que forma os mesmos decidiram a respeitos de crimes contra as mulheres, como por exemplo, a violação sexual. ${ }^{103} \mathrm{E}$, a partir disso, afirmou, com base no Estatuto de Roma, que a violação sexual pode ser considerada um crime de guerra, de lesa humanidade ou genocídio. ${ }^{104}$

Para definir especificamente a violência sexual, a CNV trouxe a definição da Organização Mundial da Saúde:

"quaisquer atos sexuais ou tentativas de realizar um ato sexual, comentários ou investidas sexuais não consentidos, atos para comercializar ou de outra forma controlar a sexualidade de uma pessoa através do uso da coerção, realizados por qualquer pessoa, independentemente de sua relação com a vítima, em qualquer ambiente, incluindo, sem estar limitados, a residência e o trabalho. Abrange toda ação praticada em contexto de relação de poder, quando o abusador obriga outra pessoa à prática sexual ou sexualizada contra a sua vontade, por meio da força física, de influência psicológica (intimidação, aliciamento, indução da vontade, sedução) ou do uso de armas e drogas."

Além desta definição, ao longo do texto a CNV afirmou que também constituem violência sexual golpes nos seios, golpes para provocar aborto ou afetar a capacidade de se reproduzir, choque elétrico nos genitais, sexo oral, atos físico humilhantes, andar nu diante de homens e/ou mulheres, maus-tratos

\footnotetext{
101 OEA. Convenção Interamericana para a Prevenção, Punição e Erradicação da Violência contra a Mulher ("Convenção de Belém do Pará"), 1994. Disponível em: http://www.cidh.org/basicos/portugues/m.belem.do.para.htm. Acesso em: 05 nov. 2018.

${ }_{102}$ BRASIL. Comissão Nacional da Verdade. Relatório, volume 1. Brasília: CNV, 2014, p.417. Disponível em: http://cnv.memoriasreveladas.gov.br/images/pdf/relatorio/volume_1_digital.pdf Acesso em: 05 nov. 2018.

${ }^{103}$ Ibid.

${ }^{104}$ ONU. Estatuto de Roma de la Corte Penal Internacional, 17 julio de 1998

${ }^{105}$ BRASIL. Comissão Nacional da Verdade. Relatório. Op.cit. p.418.
} 
verbais e xingamentos sexuais, ausência de privacidade para usar o banheiro, negar às mulheres artigos higiênicos, e ameaças dessas violações. ${ }^{106}$

A CNV, no capítulo 10 do relatório, definiu a violação sexual como uma penetração de natureza sexual, sem consentimento, do corpo da vítima por órgão sexual, membro ou objeto, com o uso de força ou por meio ameaça de correção. Assim, concluiu-se que o estupro é uma das formas de violação sexual. ${ }^{107}$

Cabe ressaltar que a CNV, apesar de seguir parâmetros semelhantes aos da Corte IDH, como a utilização da CEDAW e dos Tribunais Internacionais, não usou a jurisprudência da mesma para definir a violência sexual e a violação sexual, nem para ajudar na interpretação de situações semelhantes. O Brasil faz parte do Sistema Interamericano de Direitos Humanos e aceitou a competência da Corte IDH. Cabe ressaltar que a própria CNV é uma reparação que a Corte IDH determinou no caso Guerrilha do Araguaia vs Brasil ${ }^{108}$, ilustrando a importância do tribunal para o Estado brasileiro e para a criação da própria CNV. O GT chegou a utilizar a Convenção de Belém do Pará, que faz parte do Sistema Interamericano, porém, não foi além, não usou casos que aplicaram a mesma.

Ao tratar da dimensão sexual e de gênero da tortura, a $\mathrm{CNV}$ poderia ter utilizado casos como Penal Miguel Castro Castro vs Peru, Fernandez Ortega vs México, Rosendo Cantu vs México, J. vs Peru, Espinoza Gonzáes vs Peru, pois todos tratam da violência estatal contra a mulher, como foi demonstrado no capítulo anterior. Inclusive, se a CNV tivesse utilizado a jurisprudência do Sistema Interamericano, poderia haver uma relação entre o relatório da CNV e a posterior sentença do caso Favela Nova Brasília vs Brasil, de 2017, tendo em vista que a mesma trata de um caso brasileiro.

\footnotetext{
106 BRASIL. Comissão Nacional da Verdade. Relatório, volume 1. Brasília: CNV, 2014, p.419-420. Disponível em: http://cnv.memoriasreveladas.gov.br/images/pdf/relatorio/volume_1_digital.pdf Acesso em: 05 nov. 2018.

${ }^{107}$ Ibid. p. 418.

${ }^{108}$ Corte IDH. Caso Gomes Lund y otros ("Guerrilha do Araguaia”) vs Brasil (2010). p. 106-107.
} 
Desta forma, a CNV perdeu uma grande oportunidade de abordar a jurisprudência da Corte Interamericana para que depois a mesma pudesse ajudar a dar embasamento para os casos surgidos a partir do relatório da CNV.

\subsection{Relatos da Violência Sofrida pelas Mulheres durante a Ditadura}

A Comissão Nacional da Verdade constatou que prática de violência sexual ocorria de forma generalizada em toda estrutura repressiva, inserida na lógica da tortura, apresentada anteriormente. A estrutura social baseada na hierarquia de gênero e sexualidade ficou explícita na violência realizada pelo aparato estatal ao tratar o feminino como algo inferior e vincular a violência à masculinidade. Os testemunhos colhidos pelo grupo de trabalho "Ditadura e Gênero" citam o DEIC, o DOI-CODI, o DOPS, a Base Aérea do Galeão, batalhões da Polícia do Exército, a Casa da Morte, o Cenimar, o Cisa, delegacias de polícia, a Oban, hospitais militares, presídios e quartéis. Com base em todo material analisado pela $\mathrm{CNV}$ pode-se concluir que foram inúmeros os tipos de tortura sexual praticados durante o período da Ditadura Militar. ${ }^{109}$

O Capítulo $10^{110}$ se concentra nas mulheres, porém também considera homens como vítimas da violência sexual ocorrida na ditadura. Cabe ressaltar que esse foi o tema inicial do capítulo, sendo os cinco primeiros depoimentos desconsiderando o introdutório- são de homens e o sexto é o de uma mulher abordando o sofrimento do homem. Para o Grupo de Trabalho Ditadura e Gênero, a violência sexual contra os homens estava diretamente ligada à orientação heteronormativa, pois buscava afetar a virilidade ou acabar com a masculinidade dos presos. ${ }^{111}$

Nos locais em que a tortura era utilizada como forma de poder e dominação, estereótipos ligados ao feminino e ao masculino foram usados como

\footnotetext{
109 BRASIL. Comissão Nacional da Verdade. Relatório, volume 1. Brasília: CNV, 2014, p.421. Disponível em: http://cnv.memoriasreveladas.gov.br/images/pdf/relatorio/volume_1_digital.pdf Acesso em: 05 nov. 2018.

${ }^{110}$ O Capítulo 10 refere-se também aos homens, crianças e adolescentes como vítimas. No entanto, optouse por priorizar o testemunho das mulheres.

${ }^{111}$ BRASIL. Comissão Nacional da Verdade. Relatório. Op.cit. p.413.
} 
forma de violência contra os perseguidos políticos, considerados prisioneiras e prisioneiros. Desta forma, ao perpetrar a violência contra as mulheres, os agentes as tratavam com o que consideravam ser identidades femininas ilegítimas e faziam referência ao fato de terem se afastado de seus "lugares de esposa e mãe" e terem ousado participar da política. Porém, simultaneamente, eram tratadas segundo categorias consideradas masculinas, como força e resistência físicas. $\mathrm{O}$ depoimento de Izabel Fávero à CNV ilustra essa violência:

"Eu fui muito ofendida, como mulher, porque ser mulher e militante é um karma, a gente além de ser torturada física e psicologicamente, a mulher é vadia, a palavra mesmo era "puta", "menina decente, olha para a sua cara, com essa idade, olha o que tu está fazendo aqui, que educação os teus pais te deram, tu é uma vadia, tu não presta", enfim, eu não me lembro bem se no terceiro, no quarto dia, eu entrei em processo de aborto, eu estava grávida de dois meses, então, eu sangrava muito, eu não tinha como me proteger, eu usava papel higiênico, e já tinha mal cheiro, eu estava suja, e eu acho que, eu acho não eu tenho quase certeza que eu não fui estuprada, porque era constantemente ameaçada, porque eles tinham nojo de mim [...]. E o meu marido dizia, "por favor não façam nada com ela, pode me torturar, mas ela está grávida", e eles riam, debochavam, "isso é história, ela é suja, mas não tem nada a ver", enfim. Em nenhum momento isso foi algum tipo de preocupação, em relação [...]. Eu certamente abortei por conta dos choques que eu tive nos primeiros dias, nos órgãos genitais, nos seios, ponta dos dedos, atrás das orelhas, aquilo provocou, obviamente, um desequilíbrio, [...].,"112

Além disso, o aparato repressivo para afetar a "honra" dos homens utilizava o corpo de "suas mulheres". Desta forma, ameaçavam estuprar as esposas e filhas dos presos políticos. Com base nos depoimentos presentes no relatório $^{113}$, esse tipo de violência fica ainda mais clara nos casos em que companheiros foram torturados juntos e que as presas foram violadas na frente dos parceiros.

Muitos relatos fizeram referência às violências verbais e físicas que rotulavam as mulheres e que, com isso, justificavam as violações sexuais. Um deles é o da Karen Keilt que foi presa com seu marido em 1976 e só foram liberados com o pagamento de 400 mil dólares. Segue parte de sua narrativa:

\footnotetext{
112 Depoimento de Izabel Fávero. BRASIL. Comissão Nacional da Verdade. Relatório, volume 1. Brasília: $\quad$ CNV, $2014, \quad$ p.400. $\quad$ Disponível http://cnv.memoriasreveladas.gov.br/images/pdf/relatorio/volume_1_digital.pdf Acesso em: 05 nov. 2018.

${ }^{113}$ Relato de Eliete Lisboa Martella, que relatou o sofrimento de João Leonardo da Silva Rocha. BRASIL. Comissão Nacional da Verdade. Relatório. Op.cit. p.404.
} 
"Começaram a me bater. Eles me colocaram no pau de arara. Eles me amarraram. Eles me deram batidas. Deram choque. Eles começaram dando choque no peito. No mamilo. [...] Eu desmaiei. [...] Eu comecei a sangrar. Da boca. Sangrava de tudo quanto era... da vagina, sangrava. Nariz, boca... E eu estava muito, muito mal. [...] Veio um dos guardas e me levou para o fundo das celas e me violou. [...] Ele falou que eu era rica, mas eu tinha a buceta igual a de qualquer outra mulher. Ele era horrível [choro]. [...]",114

Lucia Murat contou em seu relato ter sido vítima de tortura sexual e se tentasse se proteger acabaria provocando sua própria morte:

"Foi nesse quadro, na volta, que o próprio Nagib fez o que ele chamava de "tortura sexual científica". Eu ficava nua, com o capuz na cabeça, uma corda enrolada no pescoço, passando pelas costas até as mãos, que estavam amarradas atrás da cintura. Enquanto o torturador ficava mexendo nos meus seios, na minha vagina, penetrando com o dedo na vagina, eu ficava impossibilitada de me defender, pois, se eu movimentasse os meus braços para me proteger, eu me enforcava e, instintivamente, eu voltava atrás."

Além das formas de violência apresentadas anteriormente, está comprovado que os agentes estatais introduziam objetos, como por exemplo, fios elétricos, ou animais nas partes íntimas dos presos políticos. Também foi constatado que nas sessões de tortura eram usados produtos e objetos de fácil acesso, como álcool, ácido, canivete, vela, cigarros, cabo de vassoura e ainda animais como cobra, jacaré, barata, rato e outros insetos. Outros objetos que surgiram nos depoimentos foram cassetete, bastão elétrico, máquina de choque e furadeira. Sônia Maria de Arruda Beltrão, presa em 1972, contou a violência sofrida no período em que ficou presa:

"Teve um negócio assim, não me lembro, acho que foi na segunda noite, primeira noite, por aí. Eu pedi para ir ao banheiro e me levaram para a tortura. [...] Então, imediatamente, você relaciona a ida ao banheiro com choque, com a tortura. Aí não pedi mais! Que aconteceu? Eu fiquei, fiquei urinando na cela em que eu estava. [...] Outra coisa, com relação à mulher, a primeira coisa que eles fazem é mandar você tirar a roupa toda. Então eu era, sabe, eu era aquela menina assim, tímida, mais em determinados aspectos. Nesse aspecto do corpo, eu era muito reservada. Então, pra mim foi um desastre. Me desmontou! Me desmontou totalmente! E, essa, sei lá, o isolamento, a situação pra fazer você enlouquecer mesmo!" 116

\footnotetext{
114 BRASIL. Comissão Nacional da Verdade. Relatório, volume 1. Brasília: CNV, 2014, p.405. Disponível em: http://cnv.memoriasreveladas.gov.br/images/pdf/relatorio/volume_1_digital.pdf Acesso em: 05 nov. 2018.

${ }^{115}$ Depoimento de Lucia Murat. Depoimento de Izabel Fávero. BRASIL. Comissão Nacional da Verdade. Relatório, Op.cit. p.406.

${ }^{116}$ Depoimento de Sonia Maria de Almeida Beltrão. BRASIL. Comissão Nacional da Verdade. Relatório. Op.cit. p.421.
} 
Outra questão diretamente relacionada à mulher e que era utilizada como forma de violência contra ela era a capacidade de procriar, de ter um filho e de nutrir o bebê. Essa característica da mulher trazia um sofrimento a mais, como ficou evidente no depoimento de Maria Amélia de Almeida Teles, que foi presa junto com seu marido César em dezembro de 1972:

\begin{abstract}
"Numa dessas sessões, um torturador da Operação Bandeirantes que tinha o nome de Mangabeira ou Gaeta [...] eu amarrada na cadeira do dragão, ele se masturbando e jogando a porra em cima do meu corpo. Eu não gosto de falar disso, mas eu vejo a importância desse momento de tratar a verdade e gênero pensando nessas desigualdades entre homens e mulheres, em que os agentes do Estado, os repressores usaram dessa desigualdade para nos torturar mais, de certa forma. De usar essa condição nossa. Nós fomos torturadas com violência sexual, usaram a maternidade contra nós. Minha irmã acabou tendo parto, tendo filho na prisão. [...] Nós sabemos o quanto a maternidade, o ônus da maternidade, que nós carregamos."
\end{abstract}

As especificidades que envolvem a violência de gênero e a violência sexual, presentes também em períodos democráticos, em geral contribuem para que as vítimas se tornem invisíveis, até mesmo por conta da falta de notificação dos casos, ou marginalizadas. Existe o agravante de o crime ser cometido por agentes estatais que possuem a obrigação de proteger a população, a vida e a integridade física dos mesmos. Isso torna ainda maior o sofrimento dos sobreviventes. Até hoje essas vítimas precisam lidar com as marcas físicas e psicológicas dos crimes sexuais sofridos, com a impunidade dos violadores e com a indiferença da sociedade.

A CNV trata dos diferentes tipos de danos que esse tipo de violência estatal causa às vítimas. Esses podem ser classificados como: a) dano moral, causado pelo sofrimento físico e/ou moral; b) dano ao projeto de vida, quando a pessoa fica impossibilitada de exercer o livre-arbítrio e/ou fazer escolhas com autonomia, além da perda de oportunidades de desenvolvimento pessoal; c) dano físico ou biológico, quando afeta a vida e a integridade pessoal do indivíduo. Ademais, os danos podem ser individuais, quando causados à vítima ou a pessoas próximas, ou coletivos, quando causados a comunidade ou grupo social, que

\footnotetext{
${ }^{117}$ Depoimento de Maria Amélia de Almeida Teles, BRASIL. Comissão Nacional da Verdade. Relatório, volume 1. Brasília: CNV, 2014, p.407. Disponível em: http://cnv.memoriasreveladas.gov.br/images/pdf/relatorio/volume_1_digital.pdf Acesso em: 05 nov. 2018.
} 
partilham determinada identidade coletiva. Esse tipo de dano diz respeito à ofensa a certo direito, como por exemplo, o direito à paz, e está relacionado à forma como determinada violação afetou a identidade ou projeto coletivo e como afetou a qualidade de vida e proveito efetivo dos direitos civis e políticos de determinada parte específica da população. ${ }^{118}$

Por conta da violência sofrida, para muitas vítimas o suicídio parecia ser a única possibilidade de libertação. Karen Keilt relatou ao Grupo de Trabalho:

"Na primeira semana, depois, quando eu voltei em casa, eu tentei me suicidar. [...] Eu tomei os remédios. Isso em julho, não é? Então, frio em São Paulo. Eu saí da cama no meio da noite e entrei na piscina. Consciente. O Rick me ouviu sair da cama, então ele veio e me salvou. [...] Eu não queria sobreviver de jeito nenhum. [...] O Rick começou a beber. Bebeu, bebeu, bebeu! Muito, muito e muito! Tornou-se alcoólatra! [...] Nunca se recuperou [da tortura]." 119

Desta forma, fica evidente que o fim das torturas e a saída da prisão não necessariamente significava que o sobrevivente estava livre das graves violações de direitos humanos. O depoimento de Cristina Moraes Almeida, presa aos 19 anos e tendo sofrido mutilação na região do tórax e nos seios e tendo sua perna destruída por uma furadeira, deixa evidente tal afirmação:

"Eu quero esquecer. Mas eu te pergunto: qual é o profissional, na psicologia, que vai apagar essas marcas? Não tem. Não tem. E hoje em dia eles [torturadores] dizem: eu não sei, eu não vi, não me comprometa. Olha, tacharem como torturador é um elogio. Assassino em série, sem sombra de dúvida. Eu vou igual a uma desesperada. [...] Eu quero sair deste capítulo. Porque eu estou vivendo como se fosse ontem.”,120

Além de tudo isso, a perseguição política fez com que muitos brasileiros precisassem viver de forma clandestina, o que levou também muitos outros ao exílio. E lá, mesmo longe do Brasil, muitos sofreram, como pode ser constatado no testemunho de Derlei Catarina de Luca, perseguida política que teve que fugir após seu marido ser preso:

"Deixei [meu filho], saí na estrada como uma doida, porque não tinha a menor ideia do que ia fazer da vida. Chorando, desesperada. E comecei a menstruar, menstruar. Eu menstruei do dia que eu deixei o meu filho até dois, três anos depois, em Cuba. Eu

\footnotetext{
118 BRASIL. Comissão Nacional da Verdade. Relatório, volume 1. Brasília: CNV, 2014, p.421. Disponível em: http://cnv.memoriasreveladas.gov.br/images/pdf/relatorio/volume_1_digital.pdf Acesso em: 05 nov. 2018.

${ }^{119}$ Depoimento de Karen Keilt. , BRASIL. Comissão Nacional da Verdade. Relatório, Op.cit. p.423.

${ }^{120}$ Depoimento de Cristina Moraes Almeida. BRASIL. Comissão Nacional da Verdade. Relatório. Op.cit. p.423.
} 
cheguei a 40kg, menstruava direto, direto, direto. O médico de Cuba disse que eu tinha transferido, que eu tinha feito... conversão, que eu tinha convertido leite em sangue. Eu me destruí, me acabei.",121

O "Capítulo 10 - Violência Sexual, Violência de Gênero e Violência Contra Crianças e Adolescentes", trouxe grande contribuição, ao abordar a questão de gênero, a violência contra a mulher, sua evolução no âmbito internacional e principalmente trouxe depoimentos de mulheres vítimas. Dar voz às vítimas dessas violações é essencial e o capítulo o fez de forma bem elaborada, sendo o texto constantemente ilustrado pelos testemunhos. Porém o mesmo deixou a desejar em alguns pontos. A CNV não apresentou dados estatísticos a respeito das violações nem sobre o perfil das vítimas. Não houve uma análise interseccional que levasse em consideração a posição social, a origem e a identidade étnica das mulheres vítimas. Além disso, não informa o número de pessoas que prestaram depoimento ao Grupo de Trabalho Ditadura e Gênero, nem quais os tipos de abusos sexuais sofridos por elas. A falta de um levantamento detalhado dificulta uma análise mais profunda sobre os padrões e métodos empregados pela ditadura, mesmo com os dados de capítulos anteriores, como "Tortura" e "Quadro de Violações".

Ademais, o GT não realizou todos os objetivos iniciais programados por seus integrantes. O capítulo não explorou outras experiências de mulheres na ditadura, como por exemplo, atuando em movimentos de resistência, nem abordou a continuidade dessas estruturas e práticas violentas contra a mulher que ainda estão presentes.

Por fim, como foi demonstrado anteriormente, a CNV perdeu uma grande oportunidade de utilizar a jurisprudência internacional do Sistema Interamericano de Direitos Humanos, principalmente da Corte IDH, ao abordar violência do Estado contra a mulher.

\footnotetext{
${ }^{121}$ Depoimento de Derlei Catarina de Luca. BRASIL. Comissão Nacional da Verdade. Relatório, volume 1. Brasília: CNV, 2014, p.424. Disponível em: http://cnv.memoriasreveladas.gov.br/images/pdf/relatorio/volume_1_digital.pdf Acesso em: 05 nov. 2018.
} 


\section{Capítulo 3 - Recomendações da CNV à luz das Reparações da Corte IDH}

O presente capítulo trata das reparações nas sentenças da Corte IDH nos casos analisados no Capítulo 1 e as conclusões e recomendações do relatório da CNV. Tendo em vista que a CNV foi uma reparação determinada pela Corte Interamericana no caso Guerrilha do Araguaia $^{122}$ pode-se compreender a importância dessa para não perpetuação das violações de direitos humanos. Desta forma, o capítulo busca analisar as recomendações da CNV à luz das reparações da Corte IDH. Como os casos do Tribunal e os da CNV ocorreram no passado, mas suas as sentenças e o relatório são recentes, entende-se que há uma continuação dessas violações e, por isso, as conclusões, recomendações e reparações de ambas são de suma importância para cessar as violações de direitos humanos no Brasil.

\subsection{Reparações da Corte IDH}

A Convenção Americana de Direitos Humanos prevê em seu artigo 63.1 que sejam reparadas as consequências das violações de direitos humanos, além do pagamento de indenização à parte lesada. ${ }^{123}$ Desta forma, nas sentenças da Corte IDH está sempre presente o capítulo de reparações determinadas. As reparações determinadas pela Corte IDH levam em consideração os fatos do caso analisado, o contexto em que as violações ocorreram, além da situação do Estado onde tal violação ocorreu na época em que está sendo proferida a sentença. O capítulo das reparações, em geral, é dividido em: publicação da sentença, obrigação de investigar, medida de satisfação, reabilitação, garantia de não repetição, indenizações compensatórias, gastos e custas.

\footnotetext{
${ }^{122}$ Corte IDH. Caso Gomes Lund y otros ("Guerrilha do Araguaia”) vs Brasil (2010), p. 106-107.

123 Organização dos Estados Americanos. Convenção Americana de Direitos Humanos ("Pacto de San José de Costa Rica"), 1969, art. 63.1. Disponível em: https://www.cidh.oas.org/basicos/portugues/c.convencao americana.htm. Acesso em: 05 nov. 2018.
} 
Um ponto dentro das reparações determinadas pela Corte IDH que está sempre presente é o da necessidade de publicação da sentença proferida. $O$ Tribunal entende que a mesma, por si só, já é uma forma de reparação. ${ }^{124}$

Em todos os casos analisados para o presente trabalho a Corte IDH entendeu que era necessário que o Estado iniciasse uma nova investigação dos fatos para que fossem identificados, julgados e eventualmente sancionados os responsáveis das violações de direitos humanos presentes nos casos, incluindo a violência sexual, a violação sexual e a tortura perpetradas contra as vítimas. ${ }^{125}$

$\mathrm{Na}$ sentença do caso Rosendo Cantu, para deixar claro que o México deveria fazer uma investigação séria, imparcial e efetiva, a Corte Interamericana fez menção direta ao controle de convencionalidade. O Tribunal afirmou que o Poder Judiciário deve exercer esse controle de forma ex officio entre as normas internas e a Convenção Americana, levando em consideração não só o tratado, mas também a interpretação do mesmo pela Corte IDH. O controle de convencionalidade faz com que as normas internas tenham que estar de acordo com os tratados internacionais. ${ }^{126}$

Sobre as medidas de satisfação, muitas vezes entende-se necessário que o Estado realize um ato público no qual reconheça a sua responsabilidade pelas violações de direitos humanos cometidas por seus agentes. No caso Fernandez Ortega, a Corte IDH afirmou que no ato público deveria ocorrer dentro de um ano, o estado mexicano deveria fazer referência às violações ocorridas, além do mesmo ser realizado na língua espanhola e no idioma indígena da região onde ocorreram as violações, com a presença de autoridades e membros da comunidade das vítimas. Por fim, precisava haver um acordo entre o Estado e a

\footnotetext{
${ }^{124}$ Corte IDH. Caso del Penal Miguel Castro Castro vs Peru, par. 139-140; Corte IDH. Caso Fernandez Ortega vs México (2010), p. 85-86; Corte IDH. Caso Rosendo Cantu vs México (2010), p.79-80; Corte IDH. Caso J. vs Peru (2013), p.121; Corte IDH. Caso Espinoza Gonzáles vs Peru (2014), p.110; Corte IDH. Caso Favela Nova Brasília vs Brasil (2017), p.73-74.

${ }^{125}$ Corte IDH. Caso del Penal Miguel Castro Castro vs Peru, par. 147-148; Corte IDH. Caso Fernandez Ortega vs México (2010), p. 81-84; Corte IDH. Caso Rosendo Cantu vs México (2010), p.76-79; Corte IDH. Caso J. vs Peru (2013), p.118-119; Corte IDH. Caso Espinoza Gonzáles vs Peru (2014), p.106108;Corte IDH. Caso Favela Nova Brasília vs Brasil (2017), p.71-72.

${ }^{126}$ Corte IDH. Caso Rosendo Cantu vs México (2010), p. 78.
} 
vítima ou seus representantes para decidirem o local e a data do ato de reconhecimento. $^{127}$

Acerca da reabilitação, o Tribunal entende que o Estado deve fornecer assistência médica para que haja uma reabilitação da vítima e de seus familiares ${ }^{128}$ nos casos em que os mesmos sofreram danos físicos e psicológicos. Essa medida é aplicável mesmo nos casos em que a sentença foi proferida muitos anos depois, como ocorreu nos casos Penal Miguel Castro Castro e J., ambos com relação ao Estado peruano. ${ }^{129}$

As garantias de não repetição são variáveis de acordo com a situação do caso concreto e de como o Estado encontra-se no momento da sentença, como por exemplo, se o mesmo já realizou alguma ação que procure impedir que determinadas violações de direitos humanos não ocorram novamente. Como o presente trabalho trata de violações do estado perpetradas contra a mulher, cabe ressaltar as medidas que a Corte Interamericana determinou no caso Espinoza Gonzáles vs Peru. A primeira medida é de caráter normativo e institucional, e esta buscava, por meio de medidas legislativas, administrativas ou de outro tipo, modificar a situação de impunidade de agentes estatais que praticassem violência sexual ou tortura. Outra medida foi a de criar um programa de formação e capacitação de funcionários estatais para que os mesmos saibam os indícios de quando houve violação de direitos humanos, além de fornecer uma educação permanente em direitos humanos para as forças policiais. No caso analisado o Estado havia iniciado algumas das medidas, no entanto, a sentença reitera a necessidade de que as mesmas sejam efetivadas dentro de um prazo razoável. ${ }^{130}$

\footnotetext{
${ }^{127}$ Corte IDH. Caso Fernandez Ortega vs México (2010), p. 85.

${ }^{128}$ Cabe apontar que o Tribunal já declarou em algumas oportunidades que os familiares de vítimas de violações de direitos humanos podem ser consideradas vítimas. Desta forma, a Corte Interamericana pode considerar violado o direito a integridade psíquica e moral de familiares de vítimas por conta do sofrimento que os mesmos passaram como consequência das violações sofridas por um ente querido e por conta das ações e omissões posteriores de agentes estatais com relação aos fatos ocorridos. Corte IDH. Caso Fernandez Ortega vs México (2010), p. 48; Corte IDH. Caso Rosendo Cantu vs México (2010), p.45; Corte IDH. Caso Espinoza Gonzáles vs Peru (2014), p.105.

${ }^{129}$ Corte IDH. Caso del Penal Miguel Castro Castro vs Peru, p.132; Corte IDH. Caso J. vs Peru (2013), p. 121 .

${ }^{130}$ Corte IDH. Caso Espinoza Gonzáles vs Peru (2014), p.110-113.
} 
No que diz respeito às indenizações compensatórias essas são um valor pecuniário o qual o Estado deve pagar às vítimas e seus familiares pelos danos matérias ou imateriais (morais) sofridos. ${ }^{131} \mathrm{Em}$ geral, o último ponto abordado nas reparações são as custas e gastos que as vítimas e seus familiares tiveram para levar o caso à Corte IDH e que no final devem ser pagas pelo Estado se for considerado responsável pelas violações. ${ }^{132}$

\subsection{Reparações para o Brasil no Caso Favela Nova Brasília (2017)}

A sentença do caso Favela Nova Brasília vs Brasil foi proferida em fevereiro de 2017, ou seja, depois da entrega do relatório da CNV. Os fatos do caso ocorreram em 1994 e 1995 e as violações de direitos humanos foram perpetradas por agentes estatais. Desta forma, as mesmas podem ser entendidas como a não superação dos acontecimentos do período da ditadura militar brasileira tendo em vista que não foram situações isoladas, mas que a violência policial é um problema constante, como demonstrado na sentença da Corte IDH. $^{133}$

No tocante às reparações do caso em questão serão abordadas, principalmente, as medidas relacionadas a violência sexual e de gênero. A primeira reparação tratada na sentença foi a obrigação de investigar. Com relação à violência sexual foi consolidado que deve haver uma investigação e um processo penal com perspectiva de gênero, além de linhas de investigação específicas para violência sexual e deve ser garantida a participação das vítimas durante a investigação e o julgamento. O Tribunal ressaltou ainda que a investigação deve ser realizada por funcionários capacitados em casos

\footnotetext{
${ }^{131}$ Corte IDH. Caso Fernandez Ortega vs México (2010), p. 94-97; Corte IDH. Caso Rosendo Cantu vs México (2010), p.90-92; Corte IDH. Caso J. vs Peru (2013), p.124-125; Corte IDH. Caso Espinoza Gonzáles vs Peru (2014), p.114.

${ }^{132}$ Corte IDH. Caso del Penal Miguel Castro Castro vs Peru, p. 137; Corte IDH. Caso Fernandez Ortega vs México (2010), p. 97-99; Corte IDH. Caso Rosendo Cantu vs México (2010), p.92-94; Corte IDH. Caso J. vs Peru (2013), p.125-127; Corte IDH. Caso Espinoza Gonzáles vs Peru (2014), p.114-117.

${ }^{133}$ Corte IDH. Caso Favela Nova Brasília vs Brasil (2017), p.28-31.
} 
semelhantes e em atenção à vítimas de discriminação e violência por motivos de gênero. ${ }^{134}$

A respeito da reabilitação, a Corte IDH entendeu que o estado brasileiro deveria fornecer tratamento psicológico e psiquiátrico gratuito às vítimas por meio de instituições de saúde especializadas e de forma imediata, adequada. ${ }^{135}$

Na parte das medidas de satisfação o Tribunal determinou a publicação da sentença e que fosse realizado um ato público com a criação de duas placas em memória das vítimas de cada uma das operações policiais na principal praça da Favela Nova Brasília. ${ }^{136}$

No que tange as garantias de não repetição, o primeiro tipo apresentado pela Corte Interamericana foi a adoção de políticas públicas. Nela o Tribunal afirmou ser de suma importância a existência de investigação por órgão independente e distinto de força policial, tal como o Ministério Público ou de autoridade judicial, nos casos de violência policial e em casos em que haja a suspeita de morte, tortura ou violência sexual derivados de intervenção policial. ${ }^{137}$

A Corte IDH valorou algumas medidas legislativas adotadas pelo Brasil e pelo Estado do Rio de Janeiro no que diz respeito a violência contra a mulher, como por exemplo, a criação da categoria "feminicídio", além de um local separado para o atendimento de mulheres vítimas de violência sexual no Instituto Médico Legal. No entendo, a Corte IDH afirmou que não basta a simples existência desses instrumentos legais, pois não basta a sua existência para garantir a proteção das mulheres vítimas, principalmente quando o perpetrador é agente estatal. Assim, foi considerado fundamental que o Estado continue com as ações desenvolvidas e que implemente um curso permanente e obrigatório para

\footnotetext{
${ }^{134}$ Corte IDH. Caso Favela Nova Brasília vs Brasil (2017), p.71-72.

${ }^{135}$ Ibid. p. 72-73.

${ }^{136}$ Ibid. p. $73-75$.

${ }^{137}$ Ibid. p. 75-78.
} 
todos da Polícia Civil e Militar e funcionários de saúde sobre atenção a mulheres vítimas de violência sexual. ${ }^{138}$

Outro tipo de garantia de não repetição foi a adoção de reformas legislativas na qual o Tribunal determinou que o Brasil adote medidas legislativas ou de outra índole. Entendeu-se que é de suma importância permitir que as vítimas de crimes ou seus familiares possam participar formal e efetivamente das investigações de crimes realizadas por policiais ou pelo Ministério Público. ${ }^{139}$

\subsection{Conclusões e Recomendações da CNV}

Com o intuito de promover uma reconciliação nacional ${ }^{140}$, a $\mathrm{CNV}$, o capítulo 18 do Volume I do Relatório, intitulado "Conclusões e Recomendações", apresentou conclusões e recomendações propondo "a adoção de medidas e políticas públicas para prevenir violação de direitos humanos, assegurar sua não repetição e promover a efetiva reconciliação nacional"141 . Com esse intuito, a CNV apresentou 4 conclusões e 29 recomendações, sendo estas medidas institucionais, iniciativas de alteração legislativa e medidas de seguimento das ações da $\mathrm{CNV}{ }^{142}$

A primeira conclusão da CNV é sobre a comprovação das graves violações de direitos humanos por parte do Estado brasileiro. Conclui-se que houve uma "prática sistemática de detenções ilegais e arbitrárias e de tortura, assim como o cometimento de execuções, desaparecimentos forçados e ocultação

\footnotetext{
${ }^{138}$ Corte IDH. Caso Favela Nova Brasília vs Brasil (2017), p. 79-80.

${ }^{139}$ Ibid. p. 80-81

140 “Art. $1^{\circ}$ É criada, no âmbito da Casa Civil da Presidência da República, a Comissão Nacional da Verdade, com a finalidade de examinar e esclarecer as graves violações de direitos humanos praticadas no período fixado no art. $8^{\circ}$ do Ato das Disposições Constitucionais Transitórias, a fim de efetivar o direito à memória e à verdade histórica e promover a reconciliação nacional." Lei 12.528, de novembro de 2011.

${ }^{141}$ BRASIL. Comissão Nacional da Verdade. Relatório, volume 1. Brasília: CNV, 2014, p. 962. Disponível em: http://cnv.memoriasreveladas.gov.br/images/pdf/relatorio/volume 1_digital.pdf Acesso em: 05 nov. 2018.

${ }^{142}$ Ibid. p. $962-975$.
} 
de cadáveres por agentes do Estado brasileiro." ${ }^{\text {143 }}$ A CNV chegou ao número de 191 mortos e 243 desaparecidos, com um total de 434 mortes e desaparecimentos. No entanto, a própria $\mathrm{CNV}$ afirmou que o número não é o total de mortos e desaparecidos na ditadura, esses são apenas os casos que houve comprovação. ${ }^{144}$

A conclusão seguinte aborda o caráter generalizado e sistemático das graves violações de direitos humanos. A CNV constatou que a repressão configurou-se como uma política de Estado. Como existia uma cadeia de comando organizada, foi possível concluir que as atividades de repressão foram organizadas pelo alto comando do Estado brasileiro. Desta forma foi possível excluir a ideia de que as violações teriam sido casos isolados. ${ }^{145}$

A terceira conclusão diz respeito às normas de Direito Internacional e a concepção de "crimes contra a humanidade". A CNV esclareceu o que seriam tais condutas e, ao final, afirmou que as práticas do regime militar de detenções ilegais e arbitrárias, execuções, torturas, desaparecimentos forçados e ocultação de cadáveres evidenciam o cometimento de crimes contra a humanidade. ${ }^{146}$

Por fim, a última conclusão trata da continuidade do quadro de graves violações de direitos humanos. A CNV entendeu que essa perpetuidade no campo das graves violações de direitos humanos ocorre devido aos atos ocorridos no passado não terem sido devidamente denunciados e seus perpetradores não terem sofrido qualquer tipo de responsabilização. ${ }^{147}$

Antes de iniciar a análise das recomendações da CNV, cabe ressaltar que, a pesar das violações de direitos humanos analisadas terem ocorrido no passado, as recomendações foram feitas em 2014, havendo o entendimento de que nenhuma dessas recomendações havia sido realizada até então e de que ainda

\footnotetext{
${ }^{143}$ BRASIL. Comissão Nacional da Verdade. Relatório, volume 1. Brasília: CNV, 2014, p. 962. Disponível em: http://cnv.memoriasreveladas.gov.br/images/pdf/relatorio/volume_1_digital.pdf Acesso em: 05 nov. 2018.

${ }^{144}$ Ibid. p. $962-963$.

${ }^{145}$ Ibid. p. 963

${ }^{146}$ Ibid. p. $963-964$

${ }^{147}$ Ibid. p. 964
} 
hoje são necessárias devido aos impactos que podem ter na sociedade para que mudanças com o intuito de promover mudanças e para que as violações ocorridas anteriormente não continuem sendo perpetradas.

Dentre as recomendações classificadas como medidas institucionais está o reconhecimento, pelas Forças Armadas, de sua responsabilidade institucional pela ocorrência de graves violações de direitos no período da ditadura militar (1964-1985). A recomendação seguinte tratou da responsabilização dos agentes públicos que causaram às graves violações de direitos humanos. Nesse momento a CNV se manifestou de forma contrária a existência da Lei de Anistia tendo em vista que essa não é compatível com a ordem jurídica internacional. Cabe ressaltar que esse posicionamento foi baseado na decisão da Corte IDH sobre o caso Gomes Lund e outros vs Brasil. ${ }^{148}$

Além das medidas institucionais anteriores, o relatório inclui ainda: (3) proposição de medidas administrativas e judiciais de regresso contra agentes públicos que causaram graves violações ${ }^{149}$; (4) a proibição da realização de eventos oficiais comemorando o golpe militar de $1964^{150}$; (5) a reformulação dos concursos públicos e dos processos de avaliação contínua das Forças Armadas, valorizando os temas de democracia e direitos humanos ${ }^{151}$; (6) a modificação do currículo das academias militares e policiais, para promoção da democracia e dos direitos humanos ${ }^{152}$; (7) a retificação da causa de morte no assento de óbito de pessoas mortas em decorrência de graves violações de direitos humanos ${ }^{153}$; (8) a retificação de informações na Rede de Integração Nacional de Informações de Segurança Pública, Justiça e Fiscalização (Rede Infoseg) e, de forma geral, nos registros públicos ${ }^{154}$; (9) a criação de mecanismos de prevenção e combate à

\footnotetext{
${ }^{148}$ BRASIL. Comissão Nacional da Verdade. Relatório, volume 1. Brasília: CNV, 2014, p. 964-967. Disponível em: http://cnv.memoriasreveladas.gov.br/images/pdf/relatorio/volume_1_digital.pdf Acesso em: 05 nov. 2018.

${ }^{149}$ Ibid. p. 967.

150 Ibid. p. 967.

151 Ibid. p. 967.

152 Ibid. p. 967-968.

153 Ibid. p. 968.

154 Ibid. p. 968.
} 
tortura $^{155}$; (10) a desvinculação dos institutos médicos legais, bem como dos órgãos de perícia criminal, das secretarias de segurança pública e das polícias civis $^{156}$; (11) o fortalecimento das Defensorias Públicas ${ }^{157}$; (12) a melhora do sistema prisional e do tratamento dado ao preso $^{158}$; (13) a instituição legal de ouvidorias externas no sistema penitenciário e nos órgãos a ele relacionados ${ }^{159}$; (14) o fortalecimento de Conselhos da Comunidade para acompanhar os estabelecimentos penais ${ }^{160}$; (15) a garantia de atendimento médico e psicossocial permanente às vítimas de graves violações de direitos humanos ${ }^{161}$; (16) a promoção dos valores democráticos e dos direitos humanos na educação ${ }^{162}$ e; (17) o apoio à instituição e ao funcionamento de órgão de proteção e promoção dos direitos humanos ${ }^{163}$.

As recomendações de reforma legal e constitucional indicadas pela CNV foram: (18) a revogação da Lei de Segurança Nacional ${ }^{164}$; (19) a reforma legal e a da tipificação dos atos correspondentes aos crimes contra a humanidade e ao crime de desaparecimento forçado (tendo como base o Estatuto de Roma e a sentença da CorteIDH no caso da Guerrilha do Araguaia) ${ }^{165}$; (20) a desmilitarização das polícias militares estaduais ${ }^{166}$; (21) a extinção da Justiça Militar Estadual ${ }^{167}$; (22) a exclusão de civis da jurisdição da Justiça Militar federal $^{168}$; (23) a extinção, na legislação, de referências discriminatórias das homossexualidades $^{169}$; (24) a mudança da legislação processual penal para

\footnotetext{
155 BRASIL. Comissão Nacional da Verdade. Relatório, volume 1. Brasília: CNV, 2014, p. 968. Disponível em: http://cnv.memoriasreveladas.gov.br/images/pdf/relatorio/volume_1_digital.pdf Acesso em: 05 nov. 2018.

${ }^{156}$ Ibid. p. $968-969$.

${ }^{157}$ Ibid. p. 969.

${ }^{158}$ Ibid.

${ }^{159}$ Ibid. p.969-970.

${ }^{160}$ Ibid. p. 970.

161 Ibid.

${ }^{162}$ Ibid.

${ }^{163}$ Ibid. p. $970-971$.

${ }^{164}$ Ibid. p. 971.

${ }^{165}$ Ibid.

${ }^{166}$ Ibid. p. 971-972.

${ }^{167}$ Ibid. p. 972.

${ }^{168}$ Ibid.

${ }^{169}$ Ibid.
} 
eliminação da figura do auto de resistência à prisão ${ }^{170} \mathrm{e} ;(25)$ a introdução da audiência de custódia, para prevenção da prática da tortura e de prisão ilegal. ${ }^{171}$

Por fim, foram listadas quatro recomendações com o objetivo de dar continuação às ações da própria CNV. A primeira (26) é a recomendação da criação de um órgão que continue com as investigações e recomendações da $\mathrm{CNV}$, tendo em vista de que não se chegou ao esgotamento do tema. ${ }^{172} \mathrm{~A}$ recomendação seguinte (27) é a de continuar com a busca, localização, identificação e entrega de restos mortais dos desaparecidos políticos. ${ }^{173} \mathrm{~A}$ penúltima recomendação (28) é sobre a preservação da memória das graves violações de direitos humanos. Esta visa a preservação e o tombamento de locais que foram utilizados para violação de direitos humanos, além da criação de um Museu da Memória. Ainda sobre o tema, a CNV entendeu que deveriam ser caçadas as honrarias dadas a violadores de direitos humanos e que deveria haver a alteração de locais públicos que homenageiem perpetradores de violações de direitos humanos. ${ }^{174}$ A última recomendação (29), diz respeito ao prosseguimento e fortalecimento da política de localização e abertura dos arquivos da ditadura militar. A CNV compreendeu que todas as informações relativas à repressão militar deveriam estar juntas em um único lugar, tornandoas públicas e de livre acesso. ${ }^{175}$

Pode-se perceber que a CNV não fez nenhuma referência nas conclusões ou recomendações direcionada especificamente à violência estatal contra a mulher. No entanto, as conclusões as quais a CNV chegou abordam afirmações feitas anteriormente relacionadas à violência perpetrada contra a mulher.

A existência de uma prática sistemática de tortura engloba também as violações sexuais sofridas pelas mulheres. A conclusão de que esse tipo de

\footnotetext{
${ }^{170}$ BRASIL. Comissão Nacional da Verdade. Relatório, volume 1. Brasília: CNV, 2014, p. 972. Disponível em: http://cnv.memoriasreveladas.gov.br/images/pdf/relatorio/volume_1_digital.pdf Acesso em: 05 nov. 2018.

${ }^{171}$ Ibid.

172 Ibid. p. 973.

173 Ibid. p. 974.

174 Ibid.

${ }^{175}$ Ibid. p. 975.
} 
prática era uma política de Estado também fica evidente na prática de violência contra a mulher e na violência de gênero quando a CNV afirma que essas práticas ocorriam de forma semelhante em diversos locais estatais. A terceira conclusão reitera que durante o período militar ocorreram crimes contra a humanidade e dentre eles pode-se considerar a violência sexual quando tortura. A última conclusão aborda a situação atual das violações de direitos humanos ao afirmar que existe a perpetuação dessas violações devido à impunidade dos agentes estatais do período da ditadura militar. Essa conclusão está diretamente relacionada ao caso Favela Nova Brasília no qual a Corte IDH afirmou que as violações de direitos humanos são uma prática constante, inclusive de tortura e violência sexual, por parte de agentes estatais, como demonstrado anteriormente. Desta forma, pode-se compreender que essas conclusões abrangem também a violência sexual e de gênero abordadas no relatório.

A partir das conclusões, cabe analisar as recomendações que dialogam com a violência sexual e de gênero. Com relação às medidas institucionais determinadas pela CNV a primeira delas, o reconhecimento institucional das Forças Armadas pela ocorrência das graves violações de direitos humanos diz respeito também à tortura, violência sexual e de gênero sofrida pelas mulheres. Cabe ressaltar que essa recomendação é semelhante à reparação nas sentenças da Corte IDH de que os Estados devem realizar uma ato púbico de reconhecimento. A recomendação seguinte está diretamente associada às conclusões da própria CNV e de que a partir das informações do relatório deve haver a responsabilização dos responsáveis pela graves violações de direitos humanos, como já foi afirmado especificamente pela Corte Interamericana no caso Araguaia.

As recomendações 5 e 6 abordam a educação de direitos humanos para policiais e militares, valendo para que os agentes estatais compreendam a gravidade de praticar também atos de violência sexual e de gênero. Ambas são muito semelhantes à adoção de políticas públicas apresentadas nas sentenças dos casos Favela Nova Brasília e Fernández Ortega, citados anteriormente. 
Como foi entendido pela CNV que a violência sexual é um tipo de tortura $^{176}$, quando a recomendação 9 trata da criação de mecanismos de prevenção e combate a tortura a mesma engloba a prevenção da violência sexual perpetrada por agentes estatais. As medidas institucionais 10 e 13 buscam a independência e imparcialidade dos órgãos que recebem as denúncias e que investigam as violações de direitos humanos. Essas recomendações são muito similares à outra política pública presente no caso Favela Nova Brasília, onde a Corte IDH afirma a necessidade da separação dessas investigações dos órgãos da polícia.

A última medida institucional que diz respeito à violência sexual e de gênero é a número 15 que traz a importância de assistência médica e psicossocial para as vítimas. Da mesma forma foi estabelecida essa necessidade nos casos Penal Miguel Castro Castro, J. e Favela Nova Brasília.

No que tange às recomendações de reforma legal e institucional compreende-se que a necessidade de tipificação de crimes contra a humanidade é de suma importância e o mesmo abrange também crimes de natureza sexual quando praticados em grande escala, como no caso brasileiro. A necessidade de instituir no ordenamento interno determinadas violações para alterar o quadro de impunidade já esteve presente em sentenças da Corte IDH como na do caso Espinoza Gonzáles. Além disso, as recomendações 20, 22, 24 e 25 versam sobre a desmilitarização das polícias militares estaduais, da exclusão de civis da jurisdição militar, da eliminação do "auto de resistência" e da necessidade de audiência de custódia para prevenir a tortura, respectivamente. Todas estão relacionadas às práticas atuais das polícias no Brasil e que incluem a violação de direitos humanos como a violência sexual e tortura. Essas recomendações são praticamente iguais as reparações determinadas no caso Favela Nova Brasília mesmo com uma diferença de três anos entre o relatório da CNV e a sentença do

\footnotetext{
176 BRASIL. Comissão Nacional da Verdade. Relatório, volume 1. Brasília: CNV, 2014, p. 286. Disponível em: http://cnv.memoriasreveladas.gov.br/images/pdf/relatorio/volume_1_digital.pdf Acesso em: 05 nov. 2018.
} 
caso. Isso demonstra que e o Estado brasileiro ainda precisa implementar boa parte das recomendações da própria CNV.

Por último, a respeito das recomendações, com o intuito de dar continuidade ao seu trabalho, a CNV fez menção à necessidade de preservar a memória das graves violações de direitos humanos, devendo haver a preservação de locais onde ocorreram essas violações e a criação de uma Museu da Memória. Esse tipo de recomendação possui o mesmo intuito que a sentença da Corte Interamericana tem ao determinar a inauguração de placas e monumentos comemorativos às vítimas dos casos, como foi feito no caso Favela Nova Brasília e Fernandez Ortega, demonstrado anteriormente.

Com base no demonstrado anteriormente, as conclusões e recomendações da CNV buscam alterar a situação atual das graves violações de direitos humanos por meio de um estudo e conhecimento do passado histórico da ditadura militar vivida no Brasil. Para tal, utilizou-se de recomendações muito semelhantes às reparações utilizadas na Corte IDH em suas sentenças, como foi demonstrado. Isso reforça ainda mais o grau de importância das recomendações feitas pela CNV no relatório. 


\section{Conclusão}

Este trabalho teve como principal objetivo analisar a abordagem feita pela Comissão Nacional da Verdade, no Volume I do Relatório, da violência de estado contra a mulher, tratando da violência sexual e de gênero. Essa análise foi feita com base na jurisprudência da Corte Interamericana de Direitos Humano. O primeiro capítulo abordou a jurisprudência da Corte IDH e as definições tratadas nos casos. O segundo tratou da forma como a CNV versou sobre a dimensão sexual e de gênero da tortura e foram apresentados alguns depoimentos de vítimas. No último, houve a análise das conclusões e recomendações da CNV a partir das reparações nas sentenças da Corte IDH. Ao final destes três capítulos, é fundamental fazer uma análise crítica da forma com que a CNV abordou a violência do Estado contra a mulher.

Durante a elaboração desta monografia ficou claro que houve uma preocupação especial da CNV com o tema da violência contra as mulheres com a criação do Grupo de Trabalho Ditadura e Gênero e isso deve ser valorizado. O GT contribuiu e muito ao abordar a questão de gênero, a violência contra a mulher, sua evolução no âmbito internacional e principalmente a valorização dos depoimentos das mulheres vítimas. Dar voz às vítimas dessas violações é essencial. No entanto, alguns pontos poderiam ter sido melhor elaborados. A CNV não apresentou dados estatísticos a respeito das violações nem sobre o perfil das vítimas. Faltou uma análise interseccional que abordasse a posição social, a origem e a identidade étnica das mulheres vítimas. Além disso, não informou o número de pessoas que prestaram depoimento ao Grupo de Trabalho Ditadura e Gênero, nem quais os tipos de abusos sexuais sofridos por elas. Também não tratou das outras experiências de mulheres no período, atuando na resistência, nem abordou de forma clara a continuidade dessas estruturas e práticas violentas contra a mulher que ainda estão presentes.

A partir da análise da abordagem dada pela CNV da violência do Estado contra a mulher, tratando da violência sexual como tortura, da violência de gênero e da violação sexual a CNV não usou os entendimentos da Corte IDH, 
nem suas jurisprudências para exemplificar e dar embasamento às suas definições. No relatório estão presentes jurisprudências internacionais que a própria Corte Interamericana utilizou em suas sentenças, como a Convenção de Belém do Pará, a CEDAW, o Estatuto de Roma e os julgados do Tribunal Penal Internacional. No entanto, a CNV optou por realizar sua própria interpretação a partir dessas decisões ao utilizar os julgados da Corte IDH.

A não utilização dos casos da Corte IDH pela $\mathrm{CNV}$ é pouco coerente tendo em vista que a criação de uma comissão da verdade brasileira foi uma reparação feita pela Corte Interamericana na sentença do Caso Gomes Lund e outros ("Guerrilha do Araguaia") vs. Brasil (2010). Essa sentença foi de suma importância para que a CNV fosse de fato criada. O Brasil ratificou a Convenção Americana de Direitos Humanos e aceitou a competência da Corte, havendo uma obrigação internacional e nacional a partir disso. O Estado brasileiro também deve seguir internamente os parâmetros da Corte IDH por meio de seus tribunais e instituições. Desta forma, o Sistema Interamericano ganha maior visibilidade e julgados nacionais ganham maior credibilidade.

A CNV, ao tratar da dimensão sexual e de gênero da tortura, poderia ter utilizado casos como Penal Miguel Castro Castro vs Peru, Fernandez Ortega vs México, Rosendo Cantu vs México, J. vs Peru, Espinoza Gonzáes vs Peru, pois todos tratam da violência estatal contra a mulher, como foi demonstrado no capítulo 1 deste trabalho. Em todos esses casos a Corte IDH tratou de violência e violação sexual perpetrada por agentes estatais e constatou que esse tipo de violência contra a mulher, quando praticado por agentes estatais constitui tortura, assim como foi afirmado pela CNV.

Ademais, se a CNV tivesse utilizado a jurisprudência do Sistema Interamericano, haveria uma relação ainda mais clara do relatório da $\mathrm{CNV}$ com a sentença proferida em 2017 do caso Favela Nova Brasília vs Brasil, o que daria ainda mais credibilidade internamente ao relatório e à sentença. 
No último capítulo do relatório, "Conclusões e Recomendações", a CNV poderia ter feito alguma referência direta à violência contra a mulher analisada, porém não o fez. Entretanto, as conclusões e recomendações da CNV abordam afirmações feitas anteriormente e relacionadas à violência perpetrada contra a mulher durante a ditadura militar. E, inclusive, muitas das conclusões e recomendações se assemelham às reparações feitas pela Corte Interamericana em suas sentenças.

A CNV concluiu que a existência de uma prática sistemática de tortura engloba também as violações sexuais sofridas pelas mulheres. A conclusão de que esse tipo de prática era uma política de Estado também fica evidente na perpetração da violência contra a mulher e da violência de gênero quando a CNV afirma que essas ocorriam de forma semelhante em diversos locais estatais. A terceira conclusão reitera que durante o período militar ocorreram crimes contra a humanidade e dentre eles pode-se considerar a violência sexual quando tortura. No que tange a última conclusão, ela aborda a situação atual das violações de direitos humanos ao afirmar que existe a perpetuação dessas violações devido à impunidade dos agentes estatais do período da ditadura militar. Essa conclusão está diretamente relacionada ao caso Favela Nova Brasília no qual a Corte IDH afirmou que as violações de direitos humanos são uma prática constante, inclusive de tortura e violência sexual, por parte de agentes estatais, como demonstrado no capítulo 3. Desta forma, pode-se afirmar que essas conclusões abrangem também a violência sexual e de gênero abordadas no relatório.

No que se refere às recomendações feitas pela CNV que estão relacionadas à violência contra a mulher, a grande maioria a Corte Interamericana já determinou como reparações em suas sentenças. A análise feita detalhadamente no capítulo 3 demonstrou que apesar da CNV não mencionar o Tribunal, suas recomendações, de alguma maneira, foram embasadas em decisões do mesmo.

A afirmação anterior ficou ainda mais óbvia quando foi proferida a sentença do caso Favela Nova Brasília vs. Brasil. Nela a Corte IDH trouxe como 
reparações muitas recomendações já feitas pela $\mathrm{CNV}$, como, por exemplo, a responsabilização dos perpetradores, as políticas públicas de educação de direitos humanos, a necessidade de mecanismos de prevenção e combate à tortura, imparcialidade dos órgãos que realizam as investigações das violações, assistência médica às vítimas, a desmilitarização das polícias, a necessidade de acabar com o "auto de resistência". As conclusões e recomendações da CNV estão muito próximas das reparações da Corte IDH e também procuram alterar a situação atual das graves violações de direitos humanos no Brasil por meio de um estudo e conhecimento do passado histórico da ditadura militar.

Por fim, apesar da CNV não ter aproveitado a oportunidade para utilizar a jurisprudência da Corte Interamericana no decorrer do relatório nem nas conclusões e recomendações, houve uma enorme semelhança na abordagem das definições a respeito da violência do Estado contra a mulher e das conclusões e recomendações. 


\section{Bibliografia}

ARANGO, Diana. La violencia Sexual como Tortura. Estudio jurisprudencial em la Corte Interamericana de Derechos Humanos. Revista Facultad de Derecho y Ciencias Políticas vol.44, $\mathrm{n}^{\circ} 121 /$ pg.461-502. Disponível em: <http://www.scielo.org.co/pdf/rfdcp/v44n121/v44n121a03.pdf> Acesso em: 03 nov. 2018

BRASIL. Comissão Nacional da Verdade. Relatório, volume 1. Brasília: CNV, 2014, p.283-285. Disponível em: <http://cnv.memoriasreveladas.gov.br/images/pdf/relatorio/volume_1_digital.pdf $>$ Acesso em: 05 nov. 2018.

BRASIL. Lei $n^{\circ}$ 12.528, de 18 de novembro de 2011. Cria a Comissão Nacional da Verdade no âmbito da Casa Civil da Presidência da República. Disponível em: <http://www2.camara.leg.br/legin/fed/lei/2011/lei-12528-18-novembro-2011611803-normaatualizada-pl.pdf.> Acesso em: 18 nov. 2018.

Carvalho, Claudia Paiva. Crimes Sexuais e Justiça de Transição na América Latina: Judicialização $e$ Arquivos Disponível em: <http://www.justica.gov.br/central-de-conteudo/anistia/anexos/miolo_crimessexuais_final.pdf/> Acesso em: 05 nov. 2018.

CLÉRICO, Laura; NOVELLI, Celeste. La Violencia Contra Las Mujeresen las Producciones de la Comisión y Corte Interamericana de derechos humanos. Disponível em: <https://scielo.conicyt.cl/pdf/estconst/v12n1/art02.pdf > Acesso em: 03 nov. 2018

Comissão IDH. Relatório $N^{\circ}$ 54/01 Caso 12.051, Maria da Penha Maia Fernandes. 4 de abril de 2001. Disponível em: <https://cidh.oas.org/annualrep/2000port/12051.htm> Acesso em: 07 nov. 2018.

Corte IDH. Caso Espinoza Gonzáles vs. Peru. Sentença de 20 de novembro de 2014. Disponível em: <http://www.corteidh.or.cr/docs/casos/articulos/seriec_289_esp.pdf.> Acesso em: 07 nov. 2018.

Corte IDH. Caso Favela Nova Brasília vs. Brasil. Sentença de 16 de fevereiro de $2017 . \quad$ Disponível em: <http://www.corteidh.or.cr/docs/casos/articulos/seriec_333_por.pdf> Acesso em: 07 nov. 2018.

Corte IDH. Caso Fernandez Ortega vs. México. Sentença de 30 de agosto de $2010 . \quad$ Disponível em: <http://www.corteidh.or.cr/docs/casos/articulos/seriec_215_esp.pdf> Acesso em: 07 nov. 2018. 
Corte IDH. Caso Gomes Lund e outros ("Guerrilha do Araguaia") vs. Brasil. Sentença de 24 de novembro de 2010. Disponível em: <http://www.corteidh.or.cr/docs/casos/articulos/seriec_219_por.pdf.> Acesso em: 07 nov. 2018.

Corte IDH. Caso Gonzalez e outras (Campo Algodonero) vs México. Sentença de 16 de novembro de 2009. Disponível em: <http://www.corteidh.or.cr/docs/casos/articulos/seriec_205_esp.pdf.> Acesso em: 07 nov. 2018.

Corte IDH. Caso J. vs. Peru. Sentença de 27 de novembro de 2013. Disponível em: <http://www.corteidh.or.cr/docs/casos/articulos/seriec_275_esp.pdf.>. Acesso em: 07 nov. 2018.

Corte IDH. Caso Loayza Tamayo vs Peru. Sentença de 17 de setembro de 1997. Disponível em: <http://www.corteidh.or.cr/docs/casos/articulos/seriec_33_esp.pdf> Acesso em: 07 nov. 2018.

Corte IDH. Caso Massacre de Río Negro vs. Guatemala. Sentença de 4 de setembro de 2012.2 Disponível em: <http://www.corteidh.or.cr/docs/casos/articulos/seriec_250_esp.pdf.> Acesso em: 07 nov. 2018.

Corte IDH. Caso Penal Miguel Castro Castro vs. Peru. Sentença de 25 de novembro de 2006.2 Disponível em: <http://www.corteidh.or.cr/docs/casos/articulos/seriec_160_esp.pdf> Acesso em: 07 nov. 2018.

Corte IDH. Caso Rosendo Cantu vs. México. Sentença de 31 de agosto de 2010. Disponível em: <http://www.corteidh.or.cr/docs/casos/articulos/seriec_216_esp.pdf.> Acesso em: 07 nov. 2018.

Corte IDH. Veliz Franco vs. Guatemala. Sentença de 19 de maio de 2014. Disponível em: <http://www.corteidh.or.cr/docs/casos/articulos/seriec_277_esp.pdf.> Acesso em: 07 nov. 2018.

Corte IDH. Voto Concorrente da Juíza Cecilia Medina Quiroga em relação à Sentença da Corte Interamericana de Direitos Humanos no Caso González e outras ("Campo Algodonero") vs México, Sentença de 16 de Novembro de 2009. Disponível em: <http://www.corteidh.or.cr/docs/casos/articulos/seriec_205_por.pdf.> Acesso em: 07 nov. 2018. 
Corte IDH. OPINIÓN CONSULTIVA OC-24/17, de 24 de novembro de 2017. <http://www.corteidh.or.cr/docs/opiniones/seriea_24_esp.pdf> Acesso em: 05 nov. 2018.

FALCÓN, Julissa Mantilla. La Comisión de la Verdad y Reconciliación en el Perú y la perspectiva de género: principales logros y hallazgos. Pontifícia Universidad Católica del Perú, Revista Ius et Veritas, núm. 51, 2015. Disponível em: <http://revista.ibdh.org.br/index.php/ibdh/article/view/166/167.> Acesso em: 05 nov. 2018.

FALCÓN, Julissa Mantilla. La Justicia Transicional y los Derechos de las Mujeres: Posibilidades y retos. Revista IUS ET VERITAS, $\mathrm{N}^{\circ}$ 51, Dezembro de 2015, pg. 208-223. Disponível em: <http://revistas.pucp.edu.pe/index.php/iusetveritas/article/view/15659/16096> Acesso em: 05 nov. 2018.

FERREITA-TINTA, Mónica. Primer caso internaional sobre violencia de género em la jurisprudência de la Corte Interamericana de Derechos Humanos: El caso del penal Miguel Castro Castro; un hito histórico para Latinoamérica. Revista CEJIL. Debates sobre Derechos Humanos e Sistema Interamericano, ano II, número 3, septiembre de 2007, pg.30-45. Disponível em: <http://www.corteidh.or.cr/tablas/r24778.pdf.> Acesso em: 05 nov. 2018.

OEA. Convenção Americana de Direitos Humanos ("Pacto de San José de Costa Rica”), de $1969 . \quad$ Disponível em: <https://www.cidh.oas.org/basicos/portugues/c.convencao_americana.htm.> Acesso em: 05 nov. 2018.

OEA. Convenção Interamericana para a Prevenção, Punição e Erradicação da Violência contra a Mulher ("Convenção de Belém do Pará"), 1994. Disponível em: <http://www.cidh.org/basicos/portugues/m.belem.do.para.htm> Acesso em: 05 nov. 2018.

OEA. Convenção Interamericana para Prevenir e Punir a Tortura, 1985. Disponível em: <https://www.oas.org/pt/cidh/mandato/Basicos/tortura.pdf> Acesso em: 05 nov. 2018. Acesso em: 12 out. 2018.

ONU. Convenção sobre a eliminação de todas as formas de discriminação contra a mulher, 1994. Disponível em: <http://www.onumulheres.org.br/wpcontent/uploads/2013/03/convencao_cedaw1.pdf> Acesso em: 05 nov. 2018.

ONU. Convenção sobre a eliminação de todas as formas de discriminação contra a mulher. Recomendación general $N^{o}$ 28, 16 de dezembro de 2010. Disponível em: <https://www.acnur.org/fileadmin/Documentos/BDL/2012/8338.pdf?file=filead min/Documentos/BDL/2012/8338> Acesso em: 05 nov. 2018. 
ONU. Convenção sobre a eliminação de todas as formas de discriminação contra a mulher. Recomendación general $N^{o}$ 19. Disponível em: <http://unhrt.pdhj.tl/por/violencia-contra-as-mulheres/> Acesso em: 05 nov. 2018.

ONU. Convenção contra a Tortura e outros Tratamentos Cruéis, Desumanos ou Degradantes, 1984. Disponível em: <http://pfdc.pgr.mpf.mp.br/atuacao-econteudos-de-apoio/legislacao/tortura/convencao_onu.pdf.> Acesso em: 05 nov. 2018.

ONU. Estatuto de Roma de la Corte Penal Internacional, 1998: <https://www.oas.org/36ag/espanol/doc_referencia/estatuto_roma.pdf> Acesso em: 05 nov. 2018. 